NBER WORKING PAPER SERIES

\title{
MATCH OR MISMATCH? AUTOMATIC ADMISSIONS AND COLLEGE PREFERENCES OF LOW- AND HIGH-INCOME STUDENTS
}

\author{
Jane Arnold Lincove \\ Kalena E. Cortes \\ Working Paper 22559 \\ http://www.nber.org/papers/w22559
NATIONAL BUREAU OF ECONOMIC RESEARCH
1050 Massachusetts Avenue
Cambridge, MA 02138
August 2016

Special thanks to Sandra E. Black for all her encouragement and most valued advice. We also thank Paula Arce-Trigatti, Michael Hurwitz, Jeffrey Smith, Lori Taylor, and Lisa Cook for helpful comments, as well as seminar and conference participants at the Association for Public Policy Analysis and Management, Southern Economic Association, Association for Education Finance and Policy, American Economic Association, and Texas A\&M's Bush School Quantitative Brown Bag Series. We are grateful to the Texas Workforce Data Quality Initiative at the University of Texas at Austin's Ray Marshall Center, funded by the U.S. Department of Labor. This research uses confidential data from the State of Texas supplied by the Texas Education Research Center (ERC) at UT-Austin. We gratefully acknowledge the use of these data. The views expressed are those of the authors and not the ERC or any of the funders or supporting organizations mentioned herein, including UT-Austin, Texas A\&M University, the Greater Texas Foundation, the State of Texas, or the study's sponsor. Any errors are attributable to the authors. We also thank Celeste Alexander and Cynthia Corn from the ERC for data support, and Jenna Cullinane, Matt Farber, Katherine Keisler, Chester Poulson, and Emily Weisburst for research assistance. Institutional support from UT-Austin, Texas A\&M University, and Tulane University's Murphy Institute are also gratefully acknowledged. The views expressed herein are those of the authors and do not necessarily reflect the views of the National Bureau of Economic Research.

NBER working papers are circulated for discussion and comment purposes. They have not been peer-reviewed or been subject to the review by the NBER Board of Directors that accompanies official NBER publications.

(C) 2016 by Jane Arnold Lincove and Kalena E. Cortes. All rights reserved. Short sections of text, not to exceed two paragraphs, may be quoted without explicit permission provided that full credit, including $\odot$ notice, is given to the source. 
Match or Mismatch? Automatic Admissions and College Preferences of Low- and High-Income Students

Jane Arnold Lincove and Kalena E. Cortes

NBER Working Paper No. 22559

August 2016

JEL No. I21,I23,J15

\begin{abstract}
We examine the role of information in the college matching behavior of low- and high-income students, exploiting a state automatic admissions policy that provides some students with perfect a priori certainty of college admissions. We find that admissions certainty encourages collegeready low-income students to seek more rigorous universities. Low-income students who are less college-ready are not influenced by admissions certainty and are sensitive to college entrance exams scores. Most students also prefer campuses with students of similar race, income, and high school class rank, but only highly-qualified low-income students choose institutions where they have fewer same-race and same-income peers.
\end{abstract}

Jane Arnold Lincove

Associate Professor

UMBC School of Public Policy

jlincove@umbc.edu

Kalena E. Cortes

The Bush School

Texas A\&M University

4220 TAMU

1049 Allen Building

College Station, TX 77843

NBER and IZA

kcortes@tamu.edu 


\section{Introduction}

Whether and where students enroll in college is vital to human capital accumulation and students' future success, and the opportunity to attend a high-quality university can be an important pathway for economic mobility. Despite the social and economic benefits of college quality, past studies have documented the phenomena of academic undermatch and overmatch — whereby some high-achieving students fail to enroll at highly-selective colleges while some low-achieving students do enroll at these institutions (Black and Smith 2004; Light and Strayer 2000; Dillon and Smith 2015a, 2015b). Recent studies focusing on high-achieving, low-income students find substantial academic undermatching among highly-qualified students with low family resources (Griffith and Rothstein 2009; Hoxby and Avery 2013; Hoxby and Turner 2013; Smith, Pender, and Howell 2013; Black, Cortes, and Lincove 2015a, 2015b). These students, who face the greatest potential for social mobility, fail to apply to prestigious universities despite the availability of generous financial aid. This so-called "mismatch" occurs despite evidence that college outcomes and labor market gains are quite positive for students who overmatch through university affirmative action admissions programs (Arcidiacono 2005; Dillon and Smith 2015b). Future educational, economic, and social opportunities might be diminished for low-income students who attend a less competitive university, apparently by choice, reducing the potential for upward social mobility.

The general consensus in the student-college fit literature is that most of the observed academic mismatch stems from the application behavior of students, and not from admission decisions by colleges (Dillon and Smith 2015a). Dillon and Smith (2015a) analyze matching tendencies in college enrollment behavior, and find that as income increases, otherwise similar students are more likely to "overmatch" by enrolling at an institution where average SATs scores 
or other measures of ability exceed their own, and less likely to "undermatch" by enrolling at an institution where average college quality is low. Since enrollment reflects both application decisions by students and admissions decisions by universities, Hoxby and Avery (2013) examine college application behavior and find that the tendency of high-performing low-income students to undermatch begins with college application and persists to enrollment. These tendencies exist despite admissions and financial aid policies at elite universities designed to attract low-income students. Thus, it appears that either information asymmetries or student preferences are driving this type of undermatch and subsequently limiting economic mobility for low-income students through access to elite higher education. Hoxby and Turner (2013) confirm that lack of information can influence application and enrollment behavior of low-income high-achieving students by randomly assigning students to receive different information about college options. They find that better information enlarges students' opportunity sets, leading to enrollment at higher-ranked universities.

In this study, we further examine how student information and preferences influence academic matching by examining college selection behavior in a context where some students have perfect information about their admissions status well in advance of application deadlines. While prior studies must assume information asymmetries across income groups regarding college admissions probabilities, students in our sample perfectly know their admissions status prior to application. We do this by comparing academic matching behavior for low- and high-income students who are and are not eligible for automatic college admissions through Texas's Top 10\% Plan. These students reflect a wide diversity of ability, race/ethnicity, and income. Texas's automatic admissions policy is based on class rank alone, so we are also able to observe college choices for students not previously studied, those with automatic admissions by having achieved 
a high class rank, but also low college readiness as measured by college entrance exams (SAT or ACT test scores). For this group of students, results provide new insight into how much students consider negative signals regarding their own college readiness in determining college match, even when college admissions is guaranteed. Finally, we are able to observe both admissions and enrollment decisions in a large state university system to examine whether application matching is indicative of more meaningful matching in enrollment.

Our study also builds on prior studies of student-college fit by examining non-academic factors that can influence application and enrollment choices. Although the matching literature typically focuses on the quality of SAT or other academic matches, young adults shopping for a college are likely seeking more than just compatible SAT scores (Bastedo and Flaster 2014; Black, Cortes, and Lincove 2015b). Low-income students are more likely to be atypical students on a competitive college campus for many reasons. Most obviously, they are likely to have fewer financial resources, which might limit both academic and social opportunities. Low-income students are also more likely to come from a minority race or ethnic background, be firstgeneration college students, and to come from communities with limited educational resources, educational attainment, adult literacy, and economic opportunities. All of these demographic differences suggest that the average low-income high school graduate may have experiences and high school peers that differ greatly from the average student on a highly-selective college campus. Even when a low-income student obtains a stellar academic record worthy of admission at any elite institution, she may perceive a social gap that discourages her from considering these institutions. Thus, we also test the influence of the presence of demographically similar students on application and enrollment choices, as well as the influence of college choices of peers who 
graduated from the same high school. We refer to this type of student-college matching as "social matching" throughout the paper.

\section{Texas Top 10\% Admissions Policy}

Our primary research question focuses on the role of admissions uncertainty in studentcollege matching behavior. We exploit Texas's statewide public university admissions policy to identify students who had perfect information about their admissions status. The Texas Top 10\% Plan grants automatic admissions to all public universities to all students who achieve the top $10 \%$ in class rank within their high schools during their junior year. While many states have automatic admissions, Texas's policy is unique in two important ways. First, students are automatically admitted based solely on class rank; and second, automatically admitted students can and do choose to attend any Texas public university campus. ${ }^{1}$ Individual school districts set the criteria for class rank and provide a list of eligible students to the state each spring. Eligible students receive a notification of their guaranteed admissions status in the spring of their junior year, well prior to the fall deadlines for applying to state universities.

The Top $10 \%$ admission policy creates a unique group of students in several ways. First, these students have full information that they will be admitted to any public university in Texas, including the two elite flagship campuses of the University of Texas at Austin and Texas A\&M University at College Station, prior to making application decisions. Second, all top 10\% students are required to take SATs or ACTs and to submit an application, but admission is guaranteed regardless of entrance exam scores. Third, students are admitted regardless of high school quality or exposure to college coursework in high school. Thus, this population reflects greater variation

\footnotetext{
${ }^{1}$ Other states use multiple criteria in automatic admission such as GPA, college entrance exams, and advanced coursework, and the university systems assign automatically admitted students to campuses (see Black, Cortes, and Lincove 2016)
} 
in SAT/ACT performance, demographic diversity, and high school quality than students typically admitted to competitive universities through holistic admissions (Black, Cortes, and Lincove 2016). Finally, automatic admissions applies to all public universities in the state. It is not simply a yes or no decision to apply to or enroll in a single university. Eligible students can take advantage of the policy to enroll at campuses offering a wide range of student demographics and academic quality. This means there is still an important component of student-driven campus selection that can offer insight into the influence of various campus characteristics for high-performing high school graduates.

Texas students who are not in the top $10 \%$ must compete in uncertain holistic admissions processes, even if their SAT or ACT scores and other college readiness measures are superior to those of top 10\% students (Cortes 2010). This creates several advantages in our estimation over prior studies of student-college mismatch. Using a national sample of students with high GPAs and high SAT scores, Hoxby and Avery (2013) hypothesize that low-income students in this group are highly likely to be admitted to elite private universities. Unfortunately, the authors are unable to observe admissions results or student perceptions of admissions probabilities in their data. With our data, we are able to perfectly identify a group of students with absolute certainty of admissions upon application. We are also able to identify a comparison group of students in the top $11-25 \%$ of class rank who have a high probability of admissions in a holistic process, but without certainty. ${ }^{2}$ Finally, we are able to observe both application and enrollment behavior, so we can see if application tendencies translate to meaningful enrollment choices. ${ }^{3}$

\footnotetext{
${ }^{2}$ Unfortunately, our data do not allow us to identify a student's exact class rank. Class rank is calculated by local school districts and not reported to the state or contained in our data.

${ }^{3} \mathrm{We}$ are unable to observe college application to universities other than Texas public institution, but we can observe enrollment at all institutions in the United States through the National Student Clearinghouse (NSC).
} 


\section{Data}

Our data were provided through the Texas Education Research Center (ERC) at UT-Austin, which houses administrative data from the state's public education, higher education, and workforce systems. Our analysis includes public high school graduates from 2008 and 2009. We focus first on the subsample of students who applied to at least one Texas public four-year university. For these students, we are able to measure student demographics, high school performance outcomes, and high school experiences through K-12 administrative files. We also include aggregate high school demographics and student outcomes published annually by the Texas Education Agency (TEA) in the Academic Excellence Indicator System (AEIS).

These administrative files were merged with information provided on ApplyTexas, the common application for all public universities in Texas. Applications identify the student's eligibility for automatic admissions, SAT (or ACT equivalent) test scores, parents' educational attainment, and family income. Finally, we use university enrollment files maintained by the Texas Higher Education Coordinating Board (THECB) to identify students who enrolled as full-time freshman the fall semester following high school graduation. Our data covers all Texas public universities that were accepting students in the fall of 2008 and 2009. The Texas public university system is quite large, and we are able to include 31 campuses with 10 or more applicants from these cohorts. ${ }^{4}$ For each campus, we constructed aggregates of median SAT scores and student demographics. The aggregates were lagged to reflect the university's freshman class the year the student applied to college.

\footnotetext{
${ }^{4}$ Due to data use restrictions, we exclude five university campuses with fewer than 10 applicants across our two cohorts. These campuses had recently opened and had few operating academic programs at the time these two cohorts applied to college.
} 
The ERC administrative data includes approximately 490,000 students who graduated from a Texas public high school in spring 2008 or 2009. Of these, approximately 146,000 (approximately 30 percent of high school graduates) applied to at least one public university for fall enrollment, and 94,080 (approximately 20 percent of high school graduates, or about 64 percent of college applicants) ultimately enrolled as a full-time student on a public university campus.

\section{Empirical Strategies}

\section{A. Estimating Application and Enrollment to Different Campus Types}

In our first analysis, we examine how automatic admission status influenced student applications and enrollment to different types of public universities. Following Dillon and Smith (2015a) and Cortes and Lincove (2016), we estimate the probability of applying to and enrolling in several types of universities as a function of student and high school characteristics, observable college readiness, and eligibility for automatic admissions. To estimate the potential differential effect of perfect admissions information on low-income students, we include an interaction term for automatic admissions and student income. Following Hoxby and Avery's (2013) strategy to emphasize income differences in college information, we limit our analytic sample to students who are high-performing and either low or high income. Specifically, we include students in the top $25 \%$ by class rank with family income either below $\$ 40,000$ or above $\$ 80,000$. If information asymmetry is a significant obstacle to application and enrollment at well-matched colleges for low-income students, the interaction term represents the effect of perfect information on these students. 
Specifically, we estimate the following regression specification by Ordinary Least Squares:

(1) $y_{i s j}=\alpha_{0}+\alpha_{1} \cdot$ low income $_{i}+\alpha_{2} \cdot$ top $10 \%_{i}+\alpha_{3} \cdot$ low income $e_{i} \cdot$ top $10 \%_{i}$

$$
+\alpha_{4} \cdot X_{i}+\mu_{s}+\epsilon_{i s j}
$$

where $y_{i s j}$ is equal to one if student $i$, who graduated from high school $s$ applies to or enrolls in a university of type $j$. The variables of interest in equation (1) are low income $e_{i}$, which is equal to one if student $i$ 's family income is less than $\$ 40,000$; top $10 \%{ }_{i}$, which is equal to one if student $i$ graduated in the top $10 \%$ of her high school class triggering automatic admission; and the interaction term low income $_{i} \cdot$ top $10 \%{ }_{i}$. $X_{i}$ is a vector of student demographics and college readiness measures, $\mu_{s}$ is a high school fixed effect, and $\epsilon_{i s j}$ is a random error. Thus, we are estimating the effect of income and perfect admissions information on college choices for students with similar college readiness and who graduated from the same high school.

Equation (1) is estimated as a linear probability model for the outcomes of application and enrollment, with specifications for several college types reflecting both academic and social matching. First, we estimate equation (1) for a student's total number of applications and whether she enrolled at any Texas four-year public university. We also estimate equation (1) for three types of academic match based on the student's SAT test score compared to the campus median. ${ }^{5}$ Using Hoxby and Avery's (2013) terminology, a campus is considered a "safety school" (SAT undermatched) if the student's SAT score is more than 10 percentile points above the campus median. A campus is a "closely-matched school" if the student's SAT score is within 10 percentile points above or below the campus median. A campus is a "reach school" (SAT overmatched) if the student's SAT score is more than 10 percentile points below the campus median. We also

\footnotetext{
${ }^{5}$ Applicants to Texas public universities are required to take either the SAT or ACT. We converted all ACT scores to SAT equivalents using the College Board crosswalk. Henceforth, we will refer to this as the student's SAT score.
} 
estimate equation (1) for two college admissions types: open enrollment (non-competitive) institutions and flagship (highly competitive) campuses. Finally, we estimate the effects of social matching by estimating the probability of applying to and enrolling at a campus that has a majorityminority student body (i.e., $>50 \%$ of students are black or Hispanic).

Importantly, the probability of different types of matching is partially a function of where a student falls on the SAT score distribution. A student with sufficiently high SAT scores will have many safety schools and some closely matched schools, but no reach schools. For this student, the benefit of perfect admissions information might be to encourage application to a closely-matched campus rather than a safety school. In contrast, a student with low SATs scores will view the same college choice set as a group of reach and closely-matched campuses with no safety schools. For this student, the benefit of perfect admissions information might be to encourage application to a reach school rather than a close match. Thus, the hypothesized effect of automatic admissions is to decrease academic undermatch in students with high SATs and to increase academic overmatch in students with low SATs. Because of this difference, we also separate our analytic sample by SAT scores, estimating equation (1) separately for students with SATs in the top quartile among all Texas college applicants and students with SATs in the bottom quartile. ${ }^{6}$

\section{B. Estimating Application and Enrollment by Campus Academic and Social Match}

In our second analysis, we examine the role of academic match and other campus characteristics in campus selection. Here, we estimate the effect of student-college SAT match on

\footnotetext{
${ }^{6}$ This strategy introduces the problem that students with sufficiently high or low SAT scores could be mismatched on all college campuses. If these students are non-randomly distributed by income, this introduces potential bias into the estimation. In our sample, fewer than 3 percent of students with low SATs are overmatched on all 31 campuses, and the frequency is similar by income group and top 10\% eligibility. A larger number of high-performing students have SAT scores that are high enough to be undermatched on all campuses, and these students are substantially more likely to be high-income than low-income. Later, we provide results with and without these students who would be undermatched on all campuses. Appendix 3 provides a comparison of average characteristics between the full sample and samples excluding students who are always mismatched.
} 
college selection with conditional logit models for college application and enrollment behavior.

This empirical strategy has previously been applied to college choices by Long (2004) for enrollment, and by Hoxby and Avery (2013) and Black, Cortes, and Lincove (2015b) for applications. It is appropriate here, as it emphasizes the role of the characteristics of universities in a student's choice set on the student's choices.

Here, we estimate both college application and enrollment as:

$$
\begin{gathered}
\text { (2) } \operatorname{Pr}\left(y_{i}=j\right)=\frac{e^{Z_{i j} \cdot \beta}}{\sum_{j} e^{Z_{i j} \cdot \beta}} \\
\text { (3) } Z_{i j} \cdot \beta=\beta_{1} \cdot S A T \operatorname{Match}_{i j}+\beta_{2} \cdot X_{i j}+\beta_{3} \cdot C_{j}+\delta_{i}+\varepsilon_{i j}
\end{gathered}
$$

where $Z_{i j}$ is equal to one if student $i$ applied to (or enrolled at) campus $j$, and zero otherwise. Again, we divide our sample into groups with top-quartile and bottom-quartile SAT scores. For students with high SAT scores, SAT Match ${ }_{i j}$ indicates that the campus is a safety school where the student's SAT score is at least 10 percentile points higher than the campus median (undermatch). For students with low SAT scores, SAT Match ${ }_{i j}$ indicates that the campus is a reach school where the student's SAT score is at least 10 percentile points below the campus median (overmatch). ${ }^{7} X_{i j}$ reflects other campus characteristics that vary across students, such as

\footnotetext{
${ }^{7}$ Other researchers applying similar strategies have selected different ranges for defining a well-matched campus. Using a more complex measure of student ability and college quality, Dillon and Smith (2015a) use a larger 20 SATpercentile point range. Using a sample of elite private universities, Hoxby and Avery (2013) use a smaller range of 5 SAT-percentile points. The distribution of SAT scores among Texas public universities falls somewhere between the narrow distribution of the Hoxby and Avery sample and the wide distribution of the Dillon and Smith sample. Therefore, we selected a 10 SAT-percentile point range and tested alternatives. Our measures of mismatch are dichotomous indicators that a specific campus is undermatched (or overmatched). We also tested linear effects of the continuous distance between the student's SAT percentile and the campus median. Following Hoxby and Avery (2013), we included two separate measures - one for if the mismatch was less than 10 percentile points and a second if the mismatch was greater than 10 percentile points. This captures potential different treatment of closely matched and very mismatched campuses. Replicating the results reported here with continuous measure of mismatch, we found effects that were smaller in magnitude than Hoxby and Avery (2013) but with similar implications to what is reported here.
} 
the distance to campus, and $C_{j}$ reflects campus characteristics that are constant across students, such as tuition rates and selective admissions. $\delta_{i}$ is a student fixed effect that controls for all student characteristics that are fixed across universities, including whether the student is eligible for automatic admission. In the conditional logit model, $\delta_{i}$ identifies a choice set as belonging to a specific student. Under the assumptions of the McFadden (1973) choice model, the error term, $\varepsilon_{i j}$, is independent and identically distributed with the extreme value distribution. ${ }^{8}$

We estimate equation (2) with a data set of 31 observations per student, one observation for each of the state college campuses the student could apply to. To be included in the estimation, a student must have at least one positive outcome, so the analysis of application behavior is conditioned on application to at least one of these 31 campuses. Multiple positive outcomes occur when a student applied to more than one campus. Analysis of enrollment is conditioned on fulltime enrollment in the fall prior to graduation at one of the 31 campuses, and only one positive outcome occurs for each enrollee. Thus, the model estimates the effects of specific campus characteristics on a student's propensity to apply to or enroll on a campus relative to other state universities with different characteristics, conditioned on applying or enrolling.

The McFadden (1973) choice model includes a student fixed effect to capture withinstudent differences in behavior toward different options in a college choice set. Thus, it is not possible to directly estimate effects of student characteristics that are constant across college choices, such as income and high school class rank. To compare effects of college match quality across student characteristics, we estimate equation (2) separately for students by income and class

\footnotetext{
${ }^{8}$ In this case, we must assume that a student's decision to apply to college and unobserved applications to other universities (private or outside Texas) are irrelevant alternatives. This assumption limits the generalizability of our results to students who select into applying to college and, to some extent, to students who limit their college choices to in-state public institutions. The latter is more likely to describe low-income students with family resource constraints than high-income students.
} 
rank. For students whose class rank is in the top $10 \%$, class rank perfectly determines admissions. We compare these students to those in the top 11-25\%, who might be highly-qualified for college but experience admissions uncertainty. We then test equality of coefficients across groups through a Hausman test following seemingly unrelated estimation. The reported differences across groups (i.e., family income and class rank) are all statistically significant at $\mathrm{p}<0.05$.

\section{Descriptive Statistics}

The 2008 and 2009 high school cohorts for Texas public high schools included 490,707 graduates. Table 1 displays summary statistics for the subsets of these cohorts who applied to at least one Texas public university (column 1) and enrolled as a full-time student at a Texas public university in the fall following high school graduation (column 2). College applicants were 49 percent white, 30 percent Hispanic, 14 percent black, and 7 percent Asian, and college entrants were 52 percent white, 28 percent Hispanic, 13 percent black, and 7 percent Asian. ${ }^{9}$ The focus of this study is income differences in college matching choices. The sample offers large subsets of high- and low-income students. Based on information provided on college applications, 34 percent of college applicants were low income $(<\$ 40,000$ per year) and 35 percent were high income $(>\$ 80,000$ per year), with similar rates for enrollment. Not surprisingly, students with high class rank are overrepresented among college applicants with 23 percent of applicants and 27 percent of enrollees in the top $10 \%$, and an additional 20 percent of applicants and 23 percent of enrollees in the top $11-25 \%$.

\footnotetext{
9 The racial and ethnic make-up of college applicants and enrollees reflects the diversity of Texas high school graduates, but white and Asian students are overrepresented among college applicants and enrollees, while Hispanic students are underrepresented.
} 
In terms of academic college readiness, the sample reflects a wide range of performance on college entry exams. Applicants' average SAT (or ACT equivalent) score is 1029 with a standard deviation of 194 points. Enrollees' scores are slightly higher at 1052 average and a standard deviation of 180 points. In the analysis below, we divide students into two distinct groups with SAT scores in the bottom quartile (ranging from an average of 774 to 812 ) and SAT scores in the top quartile (ranging from an average of 1241 to 1326). Applicants and enrollees are similar in the average college-going rate of peers from the same high school at approximately 36 percent. The average distance to a public university is about 22 miles for applicants and enrollees, with a standard deviation of 20 miles.

The 31 public university campuses in our study also reflect a wide range of academic and social settings (see Appendix 1 for summary statistics for each campus). There are campuses that are majority white, majority Hispanic, and majority black. Top 10\% students enrolled in all 31 campuses, despite a large disparity in the campus average academic preparation, with average freshman SAT scores ranging from the low 800 's to over 1200. In terms of family income, campuses range from fewer than 5 percent low-income students to over 30 percent. Annual tuition varies from approximately $\$ 3,000$ up to $\$ 7,000$, but is consistently low compared to private or outof-state college options. Due to financial aid policies, the relationship between the percent lowincome and tuition is weak in Texas. For example, UT-Austin and UT-Arlington both have approximately 20 percent low-income students despite a tuition difference of nearly $\$ 4,000$. While these 31 universities might not reflect the full choice set for Texas high school seniors, they typically reflect the most affordable and accessible college options for Texans, while offering a wide range of campus characteristics. In addition, because Texas has a universal application system for all public universities, student information about Texas public universities is likely to 
be high, compared to their information about private and out-of-state options. Thus, we are able to focus on the role of information about college admissions probabilities in a setting where awareness of college options (unrelated to admissions) is relatively high.

\section{Results for Students with High SAT Scores}

\section{A. Rates of Undermatch}

We first examine SAT and other types of matching for students in the top $25 \%$ in high school class rank and SAT scores in the top 25\% among Texas public university applicants. These students are similar to Hoxby and Avery's (2013) subsample of students with both high GPAs and high SATs. Top 10\% students benefit from perfect a priori information about admission to all public universities in Texas. If admissions uncertainty contributes to undermatch behavior among high-performing students, we should observe less frequent application to safety schools and more frequent application to closely-matched schools among top $10 \%$ students than among students with lower class rank. Further, if differential undermatch among high-performing students who are low income is explained by lack of admissions information among low-income students, we should see that achieving the top $10 \%$ status has a larger negative influence on safety-school application for low-income than high-income students. In other words, automatic admission policies should fill a larger gap in admissions information for low-income than high-income students.

To estimate these effects, we divide students with top-quartile SAT scores into subgroups by class rank (top $10 \%$ or top $11-25 \%$ ) and family income (less than $\$ 40,000$ or over $\$ 80,000$ ), creating four subgroups of students. Applying our definition of student-college mismatch described above, 34.4 percent of all Texas public high school graduates who enroll at Texas public 
universities are undermatched by at least 10 percentile points in enrollment. ${ }^{10}$ Table 2 displays the rates of application and enrollment at different types of campuses for the four subgroups of students with high SAT scores. The variables in Table 2 reflect how frequently a student applied to at least one campus of each type (panel A) and how frequently a student enrolled (conditional on application) at a campus of each type (panel B). The options for SAT matching for students with high SATs are safety schools and closely-matched schools. Table 2 also displays the frequency of application and enrollment to any open-enrollment campus (which would be highly undermatched for these students given their high SAT scores), any flagship campuses (UT-Austin or TAMU-College Station), and any majority-minority campus.

On average, all four groups of students applied to more than one college campus. Although top $10 \%$ applicants are guaranteed admissions everywhere, they are either still undecided at the time of application or are waiting for financial aid offers before they choose a campus. Looking first at application (panel A of Table 2), top $10 \%$ students are more likely to apply to a safety school than a closely-matched school with 73.6 percent of low-income students and 74.9 percent of high-income students applying to at least one safety school campus, while only 43.6 percent of low-income students and 39.3 percent of high-income students applied to at least one closelymatched campus. In contrast, top $11-25 \%$ students are substantially more likely to apply to a safety school than top $10 \%$ students, regardless of income. Among high-income students, we observe similar rates of applying to at least one closely-matched campus for students with and without automatic admissions. However, among low-income students, we observe that students with

\footnotetext{
${ }^{10}$ As a robustness test, we also used a more conservative definition applied by Dillon and Smith (2015a). In this definition, students are undermatched if their SAT score is more than 20 percentile points above the campus median, and overmatched if their SAT score is more than 20 percentile points above the campus median. Among all Texas students in our sample, this degree of undermatch occurs for approximately 17 percent of applicants and 18 percent of enrolled freshmen. Conditional logit results (available on request) were similar to what is reported here across the groups of interest in this study.
} 
automatic admissions are more likely to apply to closely-matched schools (43.6 percent) than students without automatic admissions ( 27 percent). This suggests that automatic admissions might be associated with a lower propensity to apply to safety schools for both income groups, and a higher propensity to apply to closely-matched schools for low-income students only.

Turning to other measures of application matching, we also observe large differences in application rates to flagship campuses by both income and admissions status. The highest rate of application to a flagship is 86.3 percent for high-income top $10 \%$ students and the lowest rate is 38.4 percent for low-income top $11-25 \%$ students. Notably, the rate for low-income top $10 \%$ students (64.1 percent) is most similar to high-income top $11-25 \%$ students (69.1 percent), suggesting that automatic admissions may provide an equalizing influence. We also observe that low-income students regardless of high school class rank apply to majority-minority campuses at more than four times the rate of high-income students, suggesting a greater attraction to campus diversity for low-income students, who are also more likely to be black or Hispanic.

Turning to panel B of Table 2, similar differences emerge in enrollment. Notably, lowincome top $10 \%$ students have the highest rates of enrollment in closely-matched campuses of any of the four groups (30.3 percent), and are substantially less likely to enroll in safety schools than low-income students in the top 11-25\%. Parallel differences for high-income students by admissions status exist, but the differences are not as large. However, low-income students, regardless of class rank, are less likely to enroll at a flagship campus than high-income students, suggesting that factors other than SAT scores and class rank influence the decision to apply to and enroll on these elite flagship campuses, relative to other campuses with high SATs.

Overall, the summary statistics reported in Table 2 suggest that perfect information about admissions is associated with a lower rate of undermatch among students with high SATs. In 
addition, low-income students in the top $10 \%$ are less likely to undermatch in application and enrollment than any other high-SAT group, including high-income top 10\% students, but without automatic college admissions, low-income students undermatch at the highest rate of all groups. ${ }^{11}$

\section{B. Predicted Probability of Application and Enrollment to College Types}

Table 3 displays results of OLS estimation of equation (1) as a linear estimation of the probability of applying to different campus types. In addition to income, admissions status, and their interaction, these specifications also control for student demographics (race, ethnicity, gender, and whether the student's mother attended college), observable college readiness (percentile rank of SAT scores and Texas high school exit exam scores, and the number AP or IB courses completed in high school), and high school fixed effects. On average within this analytic sample, automatic admissions through top $10 \%$ significantly and substantially reduced the probability of undermatch via application to a safety school by 21.3 percentage points, and also increased the likelihood of application to a closely-matched school by 15.4 percentage points. Automatic admissions alone had no effect on application to a majority-minority campus. Being low-income, however, increased the likelihood of application to a safety school by 4.4 percentage points, and decreased the likelihood of application to a closely-matched school by 14.8 percentage points and to a flagship campus by 20.6 percentage points.

\footnotetext{
${ }^{11}$ An important caveat is that enrollment samples are reduced to include only students who enrolled at one of the 31 included public universities. It is likely that many students applied in Texas, but enrolled elsewhere - potentially in undermatched settings - while others did not enroll at all. Using National Student Clearinghouse (NSC) enrollment data, we find that 8 percent of graduates enrolled in an out-of-state or private university outside our sample. Only 3 percent of our sample of high school graduates applied to a university in our sample but enrolled outside our sample. The reason for exiting the sample likely varies across income and class rank, as high-income and higher-ranked students have greater access to private and out-of-state institutions. We use the comparison between application and enrollment to observe whether undermatch tendencies are similar in application and enrollment. For example, it is possible that undermatch in application provides a safety net that students rarely employ. Alternately, low-income students might apply to more elite institutions but then decide not to enroll even if they are admitted. In the latter case, estimations of application behavior will understate the more meaningful undermatch behavior that occurs in enrollment. However, the association measured here is imperfect due to unmeasured outcomes for some students.
} 
The interaction term indicating for low-income and top $10 \%$ student is also significant in most specifications. While there is no significant effect of the interaction on application to a safety school, low-income top $10 \%$ students are 5.5 percentage points less likely to enroll at a safety school (column 8 of Table 3) relative to the omitted high-income top $11-25 \%$ student. There is also a substantial 8.7 percentage point increase in the probability of applying to and a 6.2 percentage point increase in the probability of enrolling at a closely-matched school for lowincome top $10 \%$ students. This benefit extends to the flagship campuses with a 6.5 percentage point increase in application and 5.3 percentage point increase in enrollment.

So far, our analysis suggests that among highly-qualified high school graduates, lowincome students are more likely to undermatch, on average, than high-income students. Top 10\% eligibility reduces undermatch overall, and also appears to have a larger effect on low-income students than similar high-income students. This provides initial support for the hypothesis that information asymmetry regarding admissions probabilities is a driver of income differences in undermatch. Regarding social matching, the results in Table 3 also suggest that low-income students with high SATs are slightly more likely to apply to majority-minority campuses than high-income peers, and this difference is not affected by automatic admissions.

\section{Effects of SAT Undermatch on Campus Choice}

Table 4 displays conditional logit regression results for application behavior for students with high SAT scores by class rank (top 10\% or top 11-25\%) and income (low or high). The coefficients reported are odds ratios. Ratios smaller than one indicate that a variable is negatively associated with the probability of application, while ratios greater than one indicate that a variable is positively associated with the probability of application. All standard errors are robust to clustering within high school attended. In the baseline specification, shown in panel A, we control 
for the distance the student must travel to the campus with dummy variables indicating if the campus is within commuting distance (up to 60 miles) or close enough to visit home by car (60 to 250 miles). The reference group is a campus more than 250 miles from home. ${ }^{12}$ We also control for whether the campus is open enrollment and in-state tuition costs in thousands of dollars. Our variable of interest is a dummy variable indicating that a school is a safety school and therefore undermatched for a student with top-quartile SAT scores.

Columns 1 and 2 of panel A compare low- and high-income students with top-quartile SAT scores and class rank in the top $10 \%$. The results for the safety school variable indicate that lowincome students with automatic admissions are 15 percent less likely to apply to a campus where they will be undermatched, relative to a campus where their SAT scores are similar to or below the median. The opposite effect is estimated for high-income students with automatic admissions, who are estimated to be 68 percent more likely to apply to a safety school. The differences in effects of undermatch on these low- and high-income students are significantly different from zero $(\mathrm{p}<0.001)$.

Next, columns 3 and 4 of panel A compare low- and high-income students with top-quartile SAT scores and class rank in the top 11-25\%. Interestingly, there is not a difference in the direction of matching effects across income among these students who are not automatically admitted. Within the top $11-25 \%$, high-income students are 3.7 times more likely to apply to a safety school than a non-safety school, and low-income students are 2.3 times more likely to apply to a safety school. Thus, we observe automatically admitted low-income students behaving differently toward undermatched institutions than low-income students who are not automatically admitted. Only

\footnotetext{
${ }^{12}$ Distance is measured from the student's high school to each of the 31 university campuses. In a small number of instances of missing data on exact high school location, distance is measured as the average from other high schools within the student's school district or county.
} 
with admissions certainty are low-income students with high SAT scores significantly less likely to apply to safety schools, compared to campuses that are closer academic matches.

Application behavior is only meaningful if it leads to enrollment, and it is possible that low-income students who apply to well-matched schools actually enrolled at undermatched schools. Table 2 indicates that top $10 \%$ students applied on average to 1.5 schools, suggesting that many have not made their campus choice prior to application. To confirm that our application results persist to enrollment, we also estimated the specifications reported above for enrollment. Those results (reported in Appendix 2), confirm that low-income students with high SATs scores are meaningfully influenced by admissions information. Among students with high SAT scores, low-income top $10 \%$ students are the only group that are less likely to enroll at a safety school by a substantial 25 percent differential - compared to better academically-matched campuses, ceteris paribus. Similar to application, students are more likely to enroll in a safety school if they are in the top 11-25\%, and high-income students are always more likely to enroll in safety schools than low-income students. Thus, our analysis suggests that low-income students are less likely to apply to and enroll at undermatched campuses when they have perfect admissions information, while high-income students are more likely to apply to undermatched campuses at all class ranks.

The other control variables in the specifications reported in panel A of Table 4 provide additional insight into the income differences in college sorting behavior. Across all class ranks, the positive effect of proximity to college and application behavior is significantly and substantially larger for low-income than high-income students. For example, a low-income student with automatic admissions status is 18 times more likely to apply to a campus within commuting distance and 20 times more likely to enroll, compared to only 7 times more likely for a highincome student. Once a campus is beyond commuting distance, the effects of distance become 
more similar for high- and low-income students. The effects of tuition on application are positive for all students in the high SAT group, which suggests that students are seeking quality and location characteristics or financial aid policies that are reflected in high tuition. The effects of tuition are similar across class rank groups and are consistently larger for high-income students, who may know that they are less likely to receive financial aid if admitted.

Importantly, the results in Table 4 include a substantial number of students whose SATs were more than 10 percentile points above the median at all 31 public university campuses. As noted above and reported in Appendix 3, this is much more likely to occur among high-income students than low-income students. We may find that high-income students are more likely to apply to safety schools, because a large proportion of this group has only safety school options among Texas public universities. To address this, we re-ran the analysis reported in Table 4 with a subsample that excludes all students for whom the safety school indicator is equal to one on all 31 campuses. The results for the baseline specification are reported in panel A of Appendix 4 for application and panel B for enrollment. Log odds estimates are similar to the results shown above. Among students with at least one closely-matched option, high-income students with automatic admissions are still twice as likely to undermatch by applying to a safety school, compared to lowincome students with automatic admissions.

Overall, these results suggest that a priori postsecondary admissions information has an encouraging and, most importantly, equalizing effect by enticing low-income students with high SAT scores to apply to and enroll at campuses with higher median SAT performance. Since there is no similar effect on high-income students, this also suggests that admissions information might have an equalizing effect on access to college quality. Low-income students with high SATs and automatic admissions undermatch in enrollment with less frequency than other groups of high- 
SAT students. However, even when college admissions is guaranteed, distance to a campus appears to be a very important factor in college decisions of low-income students. This could be related to the costs of attendance or to more complex preferences for maintaining attachments to family and local social networks.

\section{Effects of Other Types of Matching}

Students, particularly those with less information about college, may be seeking a good social match as much as, or even more than, college peers with similar SAT scores. We next explore alternative hypotheses regarding college matching behavior. The first alternative hypothesis is that students are seeking similar peers (Bastardo and Flaster 2014). To test this effect, we add control variables to equation (2) that reflect the social and demographic match between students and their potential college peers. Specifically, we add control variables for the number of applicants from the student's home county and the percent of students in the prior freshman class who share the student's same race, income bracket, and class rank. Low-income students may be discouraged from applying to elite campuses if those institutions are not sufficiently diverse to offer similar peers.

Next, we explore whether students' matching behavior is associated with the college-going patterns of their high school peers. Hoxby and Avery (2013) offer the first evidence that lowincome, high-performing students who do not undermatch come from high schools where higherincome peers have previously enrolled in elite universities. Thus, students may have better information about college options through the experience of older peers. If, for example, no one from a student's high school has ever enrolled at UT-Austin, she might not perceive that campus as a realistic option, and it might be less likely that she would be encouraged to apply by teachers and counselors. Our data allows us to identify the number of prior applicants from a student's high 
school as well as the students' enrollment outcomes. To control for application patterns, we add controls to equation (2) for the number of students from the previous high school graduating class at the same high school who applied to each university and the number who ultimately enrolled at each university. These values vary within students across the 31 college campuses and also within campuses across students with different demographic characteristics or from different high schools.

\section{Matching Based on Campus Demographics}

We first add controls for the number of applicants from the same county, and percent of the same race, same income, and same rank as the student. The results for application are reported in panel B of Table 4. First, it is notable that controlling for campus demographics, the effects of the safety school indicators on low-income automatically admitted students is now positive and quite similar to the effect on similar high-income students. Thus, when two campuses have similar demographics, both high- and low-income students are more likely to apply to the undermatched campus.

More importantly, regardless of class rank, the coefficients on campus demographics are quite different for low- and high-income students. For low-income students, we estimate large, negative effects of the percent of same-race and same-income students on campus, and large positive effects of same-rank students. Conversely, high-income students are more likely to apply to campuses with greater proportions of similar students across income, race, and class rank. These differences are consistent by class rank. The results for enrollment (panel B of Appendix 2) are similar to application.

These results suggest that low-income students are more likely to apply and enroll in campuses with a smaller proportion of similar students, including students with similar income. 
Low-income students are less likely to apply to a campus with a higher proportion of other lowincome students, while high-income students are more likely to apply to a campus with a higher proportion of high-income students. This implies that both low- and high-income students are more attracted to campuses with more high-income students. All students in our high-SAT subsamples are attracted to campuses with students with similar class rank.

\section{Matching Based on High School Peers}

Finally, we test the effects of the prior behavior of high school peers on application behavior of high-SAT students by adding controls for the number of applicants and enrollees to each campus from the student's high school's prior graduation class. The results for application are shown in panel $\mathrm{C}$ of Table 4. All groups of high-SAT students are positively influenced by prior students from their high school applying to a campus. These coefficient sizes are similar between low- and high-income students, but different across class rank levels. Top 10\% applicants are most influenced by prior applicants from their high school, with each prior applicant increasing the odds of application by approximately 5 percentage points. However, a prior applicant increases the odds of application by only 3 percentage points for top $11-25 \%$ students. Interestingly, the number of prior enrollees has a small, negative effect on the application behavior of top $10 \%$ students from both the low- and high-income groups. This is likely because top $10 \%$ students are less likely to follow lower-ranked peers to less-selective institutions. Prior enrollees have no statistically significant effects on high-SAT students in the top 11-25\%.

Also, it is notable that low-income, top $10 \%$ students are still less likely to apply to safety schools with the added controls for high school peer experiences. For high-income, top $10 \%$ students only, adding high school peer controls reduces the size of the coefficient on undermatch 
to be statistically indistinguishable from zero. Again, results for enrollment (shown in panel $\mathrm{C}$ of Appendix 2) are very similar to results for application.

\section{Results for Students with Low SAT Scores}

Our results so far suggest that perfect college admissions information has the effect of discouraging undermatch among highly-qualified low-income students. A second potential effect of admissions certainty is to encourage overmatch behavior among less-qualified students. A similar effect is documented in studies of affirmative action policies that admit minority students with SAT scores below the campus average compared to white students (Arcidiacono 2005). However, automatic admissions is quite different from affirmative action because there is no admission officer judging a student's holistic college-readiness in the context of racial inequality. Overmatch is an expected outcome of Texas' Top 10\% Plan, as it provides access to all public universities to all students regardless of any other indicators of college-readiness. Overmatch with admissions certainty is an option for all top $10 \%$ students with sufficiently low SAT scores, since admissions is guaranteed regardless of college entrance exam scores. We next replicate the analysis conducted above with the focus on overmatch behavior among students with high class rank but SAT scores in the bottom quartile for Texas public university applicants.

\section{A. Rates of Overmatch}

We identify a student as applying to or enrolling at a reach school when her SAT score is more than 10 percentile points below the campus SAT median. ${ }^{13}$ Overall, 40 percent of Texas instate applicants apply to reach schools, and 33 percent of students enroll at reach schools. Rates of

\footnotetext{
${ }^{13}$ Under this definition, fewer than 3 percent of students in our analytic sample are overmatched at all institutions. See Appendix 3 for a comparison of means with and without these students. Replication of our analysis excluding these students produced similar results to what is reported below. These results are available upon request.
} 
application and enrollment for different types of campuses for low-SAT students are reported in Table 5. The SAT-matching options for these students are closely-matched schools and reach schools. We observe overmatch through application to at least one reach school among 88 percent of low-income top $10 \%$ students and 97.1 percent of high-income top $10 \%$ students. The application rates to reach schools are surprisingly high among top $11-25 \%$ students at 86.3 percent

for low-income and 96.7 percent for high-income students. Also, despite automatic admissions, enrollment rates at reach schools, conditioned on application are only 60.6 percent for low-income top $10 \%$ students, and 69 percent for high-income top $10 \%$ students. Thus, many top $10 \%$ students who applied to reach schools, regardless of income, select out of reach schools when they choose where to enroll. We also observe similar rates of application to closely-matched schools across admissions status. As in the high-SAT group, we observe that low-income students are less likely to apply to flagship campuses and more likely to apply to majority-minority campuses than highincome students. Overall, the summary statistics reported in Table 5 suggest income differences in application and enrollment behavior, but few differences due to automatic admissions and even fewer differences due the interaction of the two characteristics.

\section{B. Predicted Probability of Application and Enrollment to College Types}

Table 6 reports on results for the linear probability model estimation for students with low SATs for application choices (panel A) and enrollment choices (panel B). We find fewer (and smaller) effects of income and top $10 \%$ on these students than we did for students with high SATs. Among low-SAT students, automatic admissions significantly increases the probability of applying to a flagship university by 28.3 percentage points, and the probability of enrolling at a flagship university by 25.2 percentage points. Automatic admission also reduces the likelihood of enrolling on an open-enrollment campus by 5.9 percentage points with no significant effect on 
application. We find no effect of automatic admission, on average, on application or enrollment at reach schools, closely-matched schools, or majority-minority campuses. However, we do find significant negative effects of being low-income on the probability of applying to and enrolling in a reach school (-7.3 and -6.8 percentage points, respectively), and low-income students are 4.7 percentage points more likely to enroll at a closely-matched school. Thus, we see less overmatch, on average, among low-income students compared to similar high-income students.

The interaction between low-income and top $10 \%$ indicates whether admissions information has a larger effect on low-income students. Here with find a significant positive effect on the number of applications. When a student is both low-income and top $10 \%$, she applies to 0.25 additional schools, ceteris paribus. This suggests that automatic admissions at least leads lowincome students to consider additional college options. However, we find no positive effects of the interaction term on the probability of applying to or enrolling at a reach school, nor do we find negative effects on the probability of applying to or enrolling in a closely-matched school. We do find that the positive effect of top $10 \%$ for application to and enrollment in a flagship campus is reduced by 10 percentage points when a student is low-income, suggesting that automatic admissions makes flagship campuses accessible overall but does little to resolve the income gap in access within these subgroups of students.

\section{Effects of SAT Overmatch on Campus Choice}

Panel A of Table 7 reports the conditional logit results for our baseline specification, testing the effects of campus overmatch on application for students with low SAT scores, controlling also for distance to campus, tuition, and open-enrollment. All four subgroups of students are more likely to apply to reach schools than closely-matched schools. These effects are similar across class ranks, with significantly higher odds of overmatch for high-income than low-income students. 
Among high-income students, we estimate that a top $10 \%$ student is 2.6 times more likely to apply to a reach school, and that a top $11-25 \%$ student is 3.5 times more likely to apply to a reach school, ceteris paribus. Among low-income students, the odds of applying to a reach school are only 33 percent higher than a non-reach school for a top $10 \%$ student and 38 percent higher for a top 11$25 \%$ student. Overall, these results reveal no substantial differential effects of overmatch for students in the top $10 \%$ relative to the top $11-25 \%$. In fact, the differences work in the opposite direction with top $10 \%$ students at both income levels less influenced by academic overmatch than top $11-25 \%$ students. We also see no equalizing effects of admissions information on overmatch behavior by income. ${ }^{14}$ These results persist to enrollment (panel A of Appendix 5).

The importance of other control variables is similar to the results for high-SAT students. That is, all low-SAT students are highly sensitive to distance, with larger effects for low-income than high-income students, and larger effects for enrollment than application. A low-income top $10 \%$ student with high SATs is 53 times more likely to apply within commuting distance, compared to 30 times more likely for a high-income top $10 \%$ student. The influence of tuition is slightly negative for low-income students in the top $11-25 \%$, who are estimated to be approximately 10 percent less likely to apply for every $\$ 1,000$ in additional tuition. Conversely, low-income top $10 \%$ students and all high-income students are more likely to apply to institutions with higher tuition.

Overall, our results suggest that admissions information does not appear to trigger differential application or enrollment behavior for students with low SATs. In particular, we do

\footnotetext{
${ }^{14}$ In estimations for students in the bottom $75 \%$ (available upon request), we find even larger income gaps in access to overmatched campuses in the bottom $75 \%$ of class rank. Among this group, high-income students are able to access overmatched schools in enrollment but low-income students are not, suggesting that high-income students are more successful in the holistic admissions process.
} 
not observe within either income group that top $10 \%$ students are overmatching more often than top $11-25 \%$ students.

\section{Effects of Other Types of Matching}

\section{Matching Based on Campus Demographics}

Results for low-SAT students with added controls for campus demographics are shown in panel B of Table 7. Unlike students with high SATs, low-income students with low SATs are positively influenced by the proportion of similar students across all class ranks and across

application and enrollment (panel B of Appendix 5). Log odds estimates are smaller for top 10\% than top $11-25 \%$ students but there is little evidence of systematic differences in the way automatically admitted students with low SATs scores respond to campus demographics compared to those with admissions uncertainty. However, the sharp comparison with the results for students with high SAT scores suggests that SAT performance and not admissions certainty triggers lowincome students to seek campuses with demographically different students, while all students with low SATs apply to and enroll at campuses with higher proportions of similar students.

\section{Matching Based on High School Peers}

The results including controls for high school peers experiences on college campuses are shown in panel C of Table 7. Like, high-SAT students, low-SAT students are positively influenced by college applications of peers regardless of income and class rank. Unlike, high-SAT students, we see no negative influences of college enrollment of peers for low-income students. Our overall findings regarding overmatch are not influenced by the addition of high school peer variables. 


\section{Conclusion}

College mismatch is a serious concern for social mobility and human capital accumulation, as it implies that students are not reaching their academic best fit. While academic overmatch has been shown to have positive effects on minority attainment, frequent academic undermatch among low-income students means that socioeconomic factors might be preventing these students from achieving their full academic potential. Prior studies suggest that undermatch is a product of student decision-making (Dillon and Smith 2015a) and that it unequally affects low-income students (Hoxby and Avery 2013; Dillon and Smith 2015a). With many plausible mechanisms, Hoxby and Avery (2013) propose that a lack of information about college admissions probabilities causes the income gap in academic undermatch.

In this study, we exploit one state's automatic college admissions policy to measure student-college match tendencies in the context of perfect a priori admissions information. We find that low-income students with high SATs are less likely to undermatch when they are certain of college acceptance, relative to both similar high-income students with admissions certainty and similar low-income students with uncertain admissions. This includes a higher rate of application and enrollment to closely-matched institutions, including elite state flagship campuses. Thus, our results suggest that admissions information does influence undermatch and that higher education policies that provide perfect information, such as automatic admissions policies at public universities, are an effective strategy to reduce both undermatch overall and the gap in access between rich and poor students. However, many elite private universities, such as those included in the Hoxby and Avery (2013) study, employ holistic admissions and are therefore not able to provide admissions certainty a priori. We cannot tell from the context studied here whether less perfect signals of admissions probabilities that might be provided through holistic admissions 
process - such as encouraging phone calls or formal invitations to apply - would be equally effective.

In addition, we find that students combine admissions certainty with other information in making college decisions. For example, when low-income students have automatic admissions but low SAT scores, they are no more likely to apply to or enroll in overmatched institutions than high-income students. In our results, a priori admissions information does not appear to improve equity in access to college quality for low-income students with low SAT scores. Instead, lowincome students appear to weigh their SAT performance and SAT match more heavily than highincome students. This provides initial evidence that information might only improve equity in access at the high end of the student performance distribution. While university admissions policies might implement affirmative action by admitting low-SES students with lower-thanaverage SAT scores, it appears that the students themselves might be reluctant to enroll. Looking at racial differences in enrollment, Black, Cortes, and Lincove (2015a) find that top 10\% black students in Texas are less likely to apply to flagship institutions than white students with similar SAT scores and college readiness, and black students are more influenced by their own SAT scores than white students when making decisions regarding college academic quality.

Finally, we find that academic mismatch, as measured through SAT scores, does not fully explain student sorting. Social factors are also important. First, the indirect costs of schooling as measured through distance to campus are a substantially larger obstacle for low-income than highincome students, regardless of college qualifications or admissions information. Social matching based on student demographics is also important for all groups of students examined here. Admissions certainty does appear to alter students' college choices in relation to demographics. Low-income students with high SATs and automatic admissions respond very differently than 
other students, seeking institutions with average demographics that are different from their own instead of the same. In contrast, low-income students with low SATs do not seek demographically different students, even when they are guaranteed admissions. Universities seeking to attract a diverse student body should be mindful that low-income students often face a difficult trade-off between social and academic matching.

Overall, our results suggest complex effects of admissions information that lead highachieving, low-income students to consider choices that are outside the norm. Importantly, these effects only occur when low-income students have both high SATs and perfect admissions information. Admissions certainty alone might be insufficient to change student application behavior, as students continue to follow signals from their own SAT performance even if it is not a factor in college admissions.

\section{References}

Arcidiacono, Peter. 2005. "Affirmative Action in Higher Education: How Do Admission and Financial Aid Rules Affect Future Earnings?” Econometrica 73(5): 1477-1524.

Bastedo, Michael N., and Flaster, Allyson. 2014. "Conceptual and Methodological Problems in Research on College Undermatch." Educational Researcher 43(2): 93-99.

Black, Dan and Jeffrey A. Smith. 2004. "How Robust is the Evidence on the Effects of College Quality? Evidence from Matching." Journal of Econometrics 121(1): 99-124.

Black, Sandra E., Cortes, Kalena E., and Lincove, Jane Arnold. 2015a. "Academic Undermatching of High-Achieving Minority Students: Evidence from Race-Neutral and Holistic Admissions Policies." American Economic Review, May, 105(5): 604-610.

Black, Sandra E., Kalena E. Cortes, and Jane Arnold Lincove. 2015b. "Apply Yourself: Racial and Ethnic Differences in College Application." National Bureau of Economic Research Working Paper No. 21368.

Black, Sandra E., Kalena E. Cortes, and Jane Arnold Lincove. 2016. "Efficacy vs. Equity: What Happens When States Tinker with College Admissions in a Race-Blind Era?" Educational Evaluation and Policy Analysis, June, 38(2): 336-363. 
Cortes, Kalena E. 2010. "Do Bans on Affirmative Action Hurt Minority Students? Evidence from the Texas Top 10\% Plan.” Economics of Education Review 29(6): 1110-1124.

Cortes, Kalena E. and Jane Arnold Lincove. 2016. "Can Admissions Percent Plans Lead to Better Collegiate Fit for Minority Students?” American Economic Review, May, 106(5): 348-54.

Dillon, Eleanor W. and Jeffrey A. Smith. 2015a. "The Determinants of Mismatch between Students and Colleges." Journal of Labor Economics, forthcoming.

Dillon, Eleanor W. and Jeffrey A. Smith. 2015b. "The Consequences of Academic Match between Students and Colleges.” IZA Discussion Paper No. 9080.

Griffith, Amanda L., and Donna S. Rothstein. 2009. "Can't Get There from Here: The Decision to Apply to a Selective College.” Economics of Education Review 28(5): 620-28.

Hoxby, Caroline, and Christopher Avery. 2013. "The Missing 'One-Offs': The Hidden Supply of High-Achieving, Low-Income Students." Brookings Papers on Economic Activity (Spring): 1-65.

Hoxby, Caroline, and Sarah Turner. 2013. "Expanding College Opportunities for HighAchieving Low-Income Students." Stanford Institute for Economic Policy Research Discussion Paper No. 12-014.

Light, Audrey and Wayne Strayer. 2000. "Determinants of College Completion: School Quality or Student Ability?” Journal of Human Resources 35(2): 299-332.

Long, Bridget T. 2004. "How Have College Decisions Changed Over Time? An Application of the Conditional Logistic Choice Model." Journal of Econometrics 121(1-2): 271296.

McFadden, Daniel. 1973. Conditional Logit Analysis of Qualitative Choice Behavior, in: P. Zrembka, ed., Frontiers in Econometrics. Academic Press, New York.

Smith, Jonathan, Matea Pender, and Jessica Howell. 2013. "The Full Extent of StudentCollege Academic Undermatch." Economics of Education Review 32: 247-61. 
Table 1: Summary Statistics

of Student Characteristics for Applicants and Enrollees at Texas Public Institutions

\begin{tabular}{|c|c|c|}
\hline & $\begin{array}{c}\text { (1) } \\
\text { Applied to College }\end{array}$ & $\begin{array}{c}\text { (2) } \\
\text { Enrolled in College }\end{array}$ \\
\hline Total number of college applications & $\begin{array}{c}1.766 \\
(1.095)\end{array}$ & $\begin{array}{c}1.856 \\
(1.152)\end{array}$ \\
\hline Undermatched by 10 SAT percentile points & 0.308 & 0.344 \\
\hline Overmatched by 10 SAT percentile points & 0.403 & 0.327 \\
\hline \multicolumn{3}{|l|}{ Race and ethnicity: } \\
\hline Asian & 0.067 & 0.074 \\
\hline Black & 0.135 & 0.132 \\
\hline Hispanic & 0.303 & 0.278 \\
\hline White & 0.494 & 0.516 \\
\hline \multicolumn{3}{|l|}{ Family income: } \\
\hline Low $(<\$ 40,000$ per year $)$ & 0.335 & 0.337 \\
\hline Middle ( $\$ 40-80,000$ per year) & 0.260 & 0.269 \\
\hline High $(>\$ 80,000$ per year $)$ & 0.346 & 0.365 \\
\hline Not reported & 0.060 & 0.028 \\
\hline \multicolumn{3}{|l|}{ High school class rank: } \\
\hline Top 10\% (automatically admitted) & 0.231 & 0.274 \\
\hline Top $11-25 \%$ & 0.198 & 0.227 \\
\hline Bottom 75\% & 0.571 & 0.498 \\
\hline \multicolumn{3}{|l|}{ SAT (or ACT equivalent) test score: } \\
\hline Average test score & $\begin{array}{l}1028.70 \\
(194.49)\end{array}$ & $\begin{array}{l}1052.22 \\
(180.29)\end{array}$ \\
\hline Top quartile & 0.251 & 0.275 \\
\hline Bottom quartile & 0.252 & 0.193 \\
\hline \multicolumn{3}{|l|}{ High school characteristics: } \\
\hline College going rate of high school peers & $\begin{array}{c}0.357 \\
(0.145)\end{array}$ & $\begin{array}{c}0.359 \\
(0.143)\end{array}$ \\
\hline Distance to a flagship university & $\begin{array}{c}153.3 \\
(119.5)\end{array}$ & $\begin{array}{c}151.4 \\
(115.9)\end{array}$ \\
\hline Distance to any 4-year public university & $\begin{array}{c}21.6 \\
(19.8)\end{array}$ & $\begin{array}{l}21.8 \\
(20.1)\end{array}$ \\
\hline Number of students & 146,993 & 94,080 \\
\hline Percent of all high school graduates & $30 \%$ & $19 \%$ \\
\hline
\end{tabular}

Notes: Standard deviations are in parentheses for continuous variables. Column 1 includes graduates who applied to at least one Texas 4-year public university. Column 2 includes graduates who enrolled as a full-time student at a Texas 4-year public university in fall semester following high school graduation.

Sources: Authors' calculations based on 2008 and 2009 student cohort data from the Texas Education Research Center (ERC) at the University of Texas at Austin. Our dataset includes Texas public high school graduates from spring 2008 and spring 2009 who applied to an/or enrolled full-time at a Texas public university the following fall. Includes 31 Texas public university including flagship universities (UT-Austin and TAMU-College Station), other top $10 \%$ campuses, and open enrollment institutions. 
Table 2: College Application and Enrollment Rates for Students in the Upper Quartile of the SAT Distribution (High SATs) by High School Class Rank and Family Income

\begin{tabular}{|c|c|c|c|c|c|c|c|c|}
\hline & \multicolumn{4}{|c|}{ Panel A: Application } & \multicolumn{4}{|c|}{ Panel B: Enrollment } \\
\hline & \multicolumn{2}{|c|}{ Top $10 \%$} & \multicolumn{2}{|c|}{ Top $11-25 \%$} & \multicolumn{2}{|c|}{ Top $10 \%$} & \multicolumn{2}{|c|}{ Top $11-25 \%$} \\
\hline & $\begin{array}{c}\text { Low } \\
\text { income }\end{array}$ & $\begin{array}{c}\text { High } \\
\text { income }\end{array}$ & $\begin{array}{c}\text { Low } \\
\text { income }\end{array}$ & $\begin{array}{c}\text { High } \\
\text { income }\end{array}$ & $\begin{array}{c}\text { Low } \\
\text { income }\end{array}$ & $\begin{array}{c}\text { High } \\
\text { income }\end{array}$ & $\begin{array}{c}\text { Low } \\
\text { income }\end{array}$ & $\begin{array}{c}\text { High } \\
\text { income }\end{array}$ \\
\hline Average applications per student & $\begin{array}{c}1.501 \\
(0.841)\end{array}$ & $\begin{array}{c}1.521 \\
(0.800)\end{array}$ & $\begin{array}{c}1.589 \\
(0.965)\end{array}$ & $\begin{array}{c}1.812 \\
(1.028)\end{array}$ & $\begin{array}{c}1.516 \\
(0.853)\end{array}$ & $\begin{array}{c}1.575 \\
(0.828)\end{array}$ & $\begin{array}{c}1.602 \\
(0.968)\end{array}$ & $\begin{array}{c}1.861 \\
(1.049)\end{array}$ \\
\hline Average SAT score percentile difference & $\begin{array}{c}20.664 \\
(18.760)\end{array}$ & $\begin{array}{c}16.950 \\
(14.162)\end{array}$ & $\begin{array}{c}26.065 \\
(17.838)\end{array}$ & $\begin{array}{c}20.339 \\
(14.686)\end{array}$ & $\begin{array}{c}18.757 \\
(18.422)\end{array}$ & $\begin{array}{c}14.226 \\
(12.704)\end{array}$ & $\begin{array}{c}27.058 \\
(17.317)\end{array}$ & $\begin{array}{c}18.971 \\
(14.252)\end{array}$ \\
\hline $\begin{array}{l}\text { SAT campus fit by } 10 \text { percentile points: } \\
\text { Safety school (undermatched) }\end{array}$ & 0.736 & 0.749 & 0.904 & 0.873 & 0.478 & 0.453 & 0.672 & 0.561 \\
\hline $\begin{array}{l}\text { Closely matched school (well-matched) } \\
\text { Reach school (overmatched) }\end{array}$ & $\begin{array}{l}0.436 \\
<1 \%\end{array}$ & $\begin{array}{l}0.393 \\
<1 \%\end{array}$ & $\begin{array}{l}0.270 \\
<1 \%\end{array}$ & $\begin{array}{l}0.382 \\
<1 \%\end{array}$ & $\begin{array}{l}0.303 \\
<1 \%\end{array}$ & $\begin{array}{l}0.270 \\
<1 \%\end{array}$ & $\begin{array}{l}0.144 \\
<1 \%\end{array}$ & $\begin{array}{l}0.208 \\
<1 \%\end{array}$ \\
\hline Campus type: & & & & & & & & \\
\hline Open enrollment campus (non-competitive) & 0.050 & 0.029 & 0.087 & 0.042 & 0.026 & 0.011 & 0.052 & 0.018 \\
\hline Flagship campus (highly competitive) & 0.641 & 0.863 & 0.384 & 0.691 & 0.434 & 0.564 & 0.220 & 0.419 \\
\hline Majority black or Hispanic campus & 0.104 & 0.023 & 0.102 & 0.017 & 0.048 & $<1 \%$ & 0.055 & $<1 \%$ \\
\hline Enrolled at a public university & 0.781 & 0.723 & 0.816 & 0.768 & -- & -- & -- & -- \\
\hline Number of students & 2,643 & 10,127 & 1,136 & 3,998 & 2,065 & 7,318 & 927 & 3,071 \\
\hline
\end{tabular}

Notes: Standard deviations are in parentheses for continuous variables. College enrollment based on fall semester following high school

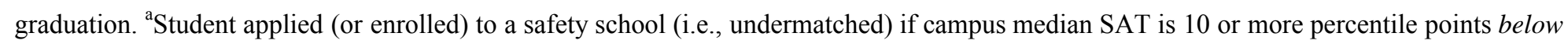

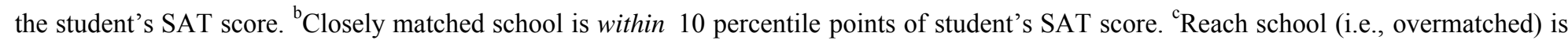
10 or more points above the student's SAT score. 
Table 3: Ordinary Least Squares Regression Results of SAT Mismatch on Application and Enrollment Choices for Students with High SATs (Upper Quartile of the SAT Distribution)

\begin{tabular}{|c|c|c|c|c|c|c|c|c|c|c|c|c|}
\hline & \multicolumn{6}{|c|}{ Panel A: Application } & \multicolumn{6}{|c|}{ Panel B: Enrollment } \\
\hline & (1) & $(2)$ & (3) & (4) & $(5)$ & $(6)$ & (7) & $(8)$ & (9) & (10) & $(11)$ & $(12)$ \\
\hline & $\begin{array}{c}\text { No. of } \\
\text { Applications }\end{array}$ & $\begin{array}{c}\text { Safety } \\
\text { School }^{\mathrm{a}}\end{array}$ & $\begin{array}{l}\text { Closely } \\
\text { Matched } \\
\text { School }^{\mathrm{b}}\end{array}$ & $\begin{array}{c}\text { Open } \\
\text { Enrollment } \\
\text { Campus }\end{array}$ & $\begin{array}{l}\text { Applied to } \\
\text { Flagship } \\
\text { Campus }\end{array}$ & $\begin{array}{c}\text { Majority- } \\
\text { minority } \\
\text { Campus }^{c}\end{array}$ & $\begin{array}{c}\text { Any Texas } \\
\text { Public } \\
\text { University }\end{array}$ & $\begin{array}{c}\text { Safety } \\
\text { School }^{\mathrm{a}}\end{array}$ & $\begin{array}{l}\text { Closely } \\
\text { Matched } \\
\text { School }^{\mathrm{b}}\end{array}$ & $\begin{array}{c}\text { Open } \\
\text { Enrollment } \\
\text { Campus }\end{array}$ & $\begin{array}{l}\text { Applied to } \\
\text { Flagship } \\
\text { Campus }\end{array}$ & $\begin{array}{c}\text { Majority- } \\
\text { minority } \\
\text { Campus }^{\mathrm{c}}\end{array}$ \\
\hline Low income & $\begin{array}{c}-0.290^{*} \\
(0.031)\end{array}$ & $\begin{array}{l}0.044^{*} \\
(0.013)\end{array}$ & $\begin{array}{l}-0.148^{*} \\
(0.014)\end{array}$ & $\begin{array}{l}0.016^{*} \\
(0.006)\end{array}$ & $\begin{array}{c}-0.206^{*} \\
(0.013)\end{array}$ & $\begin{array}{l}0.019^{*} \\
(0.005)\end{array}$ & $\begin{array}{l}0.031^{*} \\
(0.016)\end{array}$ & $\begin{array}{l}0.121^{*} \\
(0.017)\end{array}$ & $\begin{array}{l}-0.090^{*} \\
(0.014)\end{array}$ & $\begin{array}{l}0.019^{*} \\
(0.004)\end{array}$ & $\begin{array}{c}-0.127 * \\
(0.017)\end{array}$ & $\begin{array}{c}0.019 * \\
(0.004)\end{array}$ \\
\hline Top $10 \%$ & $\begin{array}{l}-0.259^{*} \\
(0.018)\end{array}$ & $\begin{array}{l}-0.213^{*} \\
(0.008)\end{array}$ & $\begin{array}{l}0.154^{*} \\
(0.008)\end{array}$ & $\begin{array}{l}-0.010^{*} \\
(0.004)\end{array}$ & $\begin{array}{l}0.158^{*} \\
(0.008)\end{array}$ & $\begin{array}{l}-0.000 \\
(0.003)\end{array}$ & $\begin{array}{l}-0.011 \\
(0.009)\end{array}$ & $\begin{array}{l}-0.171^{*} \\
(0.010)\end{array}$ & $\begin{array}{l}0.159^{*} \\
(0.008)\end{array}$ & $\begin{array}{l}-0.003 \\
(0.002)\end{array}$ & $\begin{array}{l}0.167^{*} \\
(0.010)\end{array}$ & $\begin{array}{l}-0.002 \\
(0.002)\end{array}$ \\
\hline Low income $\mathrm{x}$ Top $10 \%$ & $\begin{array}{c}0.156 * \\
(0.036)\end{array}$ & $\begin{array}{l}-0.015 \\
(0.015)\end{array}$ & $\begin{array}{c}0.087 * \\
(0.016)\end{array}$ & $\begin{array}{c}-0.017 * \\
(0.007)\end{array}$ & $\begin{array}{c}0.065^{*} \\
(0.016)\end{array}$ & $\begin{array}{c}-0.016 * \\
(0.006)\end{array}$ & $\begin{array}{c}0.006 \\
(0.018)\end{array}$ & $\begin{array}{c}-0.055^{*} \\
(0.020)\end{array}$ & $\begin{array}{c}0.062 * \\
(0.016)\end{array}$ & $\begin{array}{c}-0.012 * \\
(0.005)\end{array}$ & $\begin{array}{c}0.053 * \\
(0.020)\end{array}$ & $\begin{array}{c}-0.008 \\
(0.004)\end{array}$ \\
\hline Student characteristics: & & & & & & & & & & & & \\
\hline Black & $\begin{array}{l}0.133^{*} \\
(0.045)\end{array}$ & $\begin{array}{l}-0.017 \\
(0.019)\end{array}$ & $\begin{array}{l}0.081^{*} \\
(0.020)\end{array}$ & $\begin{array}{l}0.042^{*} \\
(0.009)\end{array}$ & $\begin{array}{l}0.047^{*} \\
(0.019)\end{array}$ & $\begin{array}{l}0.045^{*} \\
(0.007)\end{array}$ & $\begin{array}{l}-0.152 * \\
(0.022)\end{array}$ & $\begin{array}{l}-0.119^{*} \\
(0.025)\end{array}$ & $\begin{array}{l}-0.033 \\
(0.020)\end{array}$ & $\begin{array}{c}0.005 \\
(0.006)\end{array}$ & $\begin{array}{l}-0.097^{*} \\
(0.025)\end{array}$ & $\begin{array}{c}0.006 \\
(0.006)\end{array}$ \\
\hline Hispanic & $\begin{array}{l}0.142 * \\
(0.025)\end{array}$ & $\begin{array}{c}0.009 \\
(0.010)\end{array}$ & $\begin{array}{l}0.033^{*} \\
(0.011)\end{array}$ & $\begin{array}{l}-0.003 \\
(0.005)\end{array}$ & $\begin{array}{l}0.037^{*} \\
(0.011)\end{array}$ & $\begin{array}{l}0.015^{*} \\
(0.004)\end{array}$ & $\begin{array}{l}-0.092 * \\
(0.012)\end{array}$ & $\begin{array}{l}-0.070^{*} \\
(0.014)\end{array}$ & $\begin{array}{l}-0.022 * \\
(0.011)\end{array}$ & $\begin{array}{l}-0.008^{*} \\
(0.003)\end{array}$ & $\begin{array}{l}-0.051^{*} \\
(0.014)\end{array}$ & $\begin{array}{l}0.006^{*} \\
(0.003)\end{array}$ \\
\hline Asian & $\begin{array}{l}0.188^{*} \\
(0.022)\end{array}$ & $\begin{array}{l}-0.018 \\
(0.009)\end{array}$ & $\begin{array}{l}0.081 * \\
(0.010)\end{array}$ & $\begin{array}{c}0.006 \\
(0.004)\end{array}$ & $\begin{array}{l}0.032 * \\
(0.010)\end{array}$ & $\begin{array}{c}0.007 \\
(0.004)\end{array}$ & $\begin{array}{l}0.032 * \\
(0.011)\end{array}$ & $\begin{array}{l}-0.037^{*} \\
(0.012)\end{array}$ & $\begin{array}{l}0.069^{*} \\
(0.010)\end{array}$ & $\begin{array}{c}0.000 \\
(0.003)\end{array}$ & $\begin{array}{c}0.003 \\
(0.013)\end{array}$ & $\begin{array}{c}0.001 \\
(0.003)\end{array}$ \\
\hline Female & $\begin{array}{c}0.026 \\
(0.013)\end{array}$ & $\begin{array}{l}0.029^{*} \\
(0.006)\end{array}$ & $\begin{array}{l}-0.034 * \\
(0.006)\end{array}$ & $\begin{array}{l}0.010^{*} \\
(0.003)\end{array}$ & $\begin{array}{l}-0.033 * \\
(0.006)\end{array}$ & $\begin{array}{c}0.002 \\
(0.002)\end{array}$ & $\begin{array}{l}-0.057 * \\
(0.007)\end{array}$ & $\begin{array}{l}-0.020^{*} \\
(0.007)\end{array}$ & $\begin{array}{l}-0.036^{*} \\
(0.006)\end{array}$ & $\begin{array}{l}0.005^{*} \\
(0.002)\end{array}$ & $\begin{array}{l}-0.062 * \\
(0.007)\end{array}$ & $\begin{array}{c}0.001 \\
(0.002)\end{array}$ \\
\hline Mother went to college & $\begin{array}{l}0.179^{*} \\
(0.018)\end{array}$ & $\begin{array}{l}-0.003 \\
(0.008)\end{array}$ & $\begin{array}{l}0.044^{*} \\
(0.008)\end{array}$ & $\begin{array}{l}0.012 * \\
(0.004)\end{array}$ & $\begin{array}{l}0.016^{*} \\
(0.008)\end{array}$ & $\begin{array}{c}0.001 \\
(0.003)\end{array}$ & $\begin{array}{l}0.026^{*} \\
(0.009)\end{array}$ & $\begin{array}{c}0.006 \\
(0.010)\end{array}$ & $\begin{array}{l}0.020^{*} \\
(0.008)\end{array}$ & $\begin{array}{l}0.005^{*} \\
(0.002)\end{array}$ & $\begin{array}{l}0.028^{*} \\
(0.010)\end{array}$ & $\begin{array}{l}-0.000 \\
(0.002)\end{array}$ \\
\hline College readiness: & & & & & & & & & & & & \\
\hline SAT/ACT percentile & $\begin{array}{c}0.218 \\
(0.287)\end{array}$ & $\begin{array}{l}1.232 * \\
(0.122)\end{array}$ & $\begin{array}{c}-1.084 * \\
(0.132)\end{array}$ & $\begin{array}{c}-0.184 * \\
(0.057)\end{array}$ & $\begin{array}{c}0.813^{*} \\
(0.125)\end{array}$ & $\begin{array}{c}-0.097^{*} \\
(0.045)\end{array}$ & $\begin{array}{l}1.257^{*} \\
(0.144)\end{array}$ & $\begin{array}{l}2.603 * \\
(0.159)\end{array}$ & $\begin{array}{c}-1.346^{*} \\
(0.129)\end{array}$ & $\begin{array}{c}-0.097^{*} \\
(0.038)\end{array}$ & $\begin{array}{l}1.705^{*} \\
(0.162)\end{array}$ & $\begin{array}{c}-0.061 \\
(0.036)\end{array}$ \\
\hline Exit exam percentile & $\begin{array}{c}-0.116^{*} \\
(0.057)\end{array}$ & $\begin{array}{c}-0.100 * \\
(0.024)\end{array}$ & $\begin{array}{c}0.070 * \\
(0.026)\end{array}$ & $\begin{array}{c}-0.023 * \\
(0.011)\end{array}$ & $\begin{array}{c}0.076^{*} \\
(0.025)\end{array}$ & $\begin{array}{c}-0.021 * \\
(0.009)\end{array}$ & $\begin{array}{c}0.011 \\
(0.029)\end{array}$ & $\begin{array}{l}-0.056 \\
(0.032)\end{array}$ & $\begin{array}{c}0.067 * \\
(0.026)\end{array}$ & $\begin{array}{c}-0.031 * \\
(0.008)\end{array}$ & $\begin{array}{c}0.081 * \\
(0.032)\end{array}$ & $\begin{array}{c}-0.007 \\
(0.007)\end{array}$ \\
\hline AP/IB semesters completed & $\begin{array}{c}-0.006^{*} \\
(0.002)\end{array}$ & $\begin{array}{c}-0.007 * \\
(0.001)\end{array}$ & $\begin{array}{c}0.007^{*} \\
(0.001)\end{array}$ & $\begin{array}{c}-0.002 * \\
(0.000)\end{array}$ & $\begin{array}{l}0.010^{*} \\
(0.001)\end{array}$ & $\begin{array}{c}-0.001 * \\
(0.000)\end{array}$ & $\begin{array}{c}-0.004 * \\
(0.001)\end{array}$ & $\begin{array}{c}-0.009 * \\
(0.001)\end{array}$ & $\begin{array}{l}0.005^{*} \\
(0.001)\end{array}$ & $\begin{array}{c}-0.001 * \\
(0.000)\end{array}$ & $\begin{array}{l}0.005^{*} \\
(0.001)\end{array}$ & $\begin{array}{c}-0.000 \\
(0.000)\end{array}$ \\
\hline Constant & $\begin{array}{l}2.858^{*} \\
(0.107)\end{array}$ & $\begin{array}{c}-1.698^{*} \\
(0.045)\end{array}$ & $\begin{array}{l}4.416^{*} \\
(0.049)\end{array}$ & $\begin{array}{l}0.108^{*} \\
(0.021)\end{array}$ & $\begin{array}{c}0.348^{*} \\
(0.047)\end{array}$ & $\begin{array}{c}0.095^{*} \\
(0.017)\end{array}$ & $\begin{array}{l}1.656^{*} \\
(0.053)\end{array}$ & $\begin{array}{c}-1.398^{*} \\
(0.059)\end{array}$ & $\begin{array}{l}3.054^{*} \\
(0.048)\end{array}$ & $\begin{array}{l}0.054^{*} \\
(0.014)\end{array}$ & $\begin{array}{l}0.888^{*} \\
(0.060)\end{array}$ & $\begin{array}{l}0.045^{*} \\
(0.013)\end{array}$ \\
\hline No. of students & 17,904 & 17,904 & 17,904 & 17,904 & 17,904 & 17,904 & 17,904 & 17,904 & 17,904 & 17,904 & 17,904 & 17,904 \\
\hline High School Fixed Effects & Yes & Yes & Yes & Yes & Yes & Yes & Yes & Yes & Yes & Yes & Yes & Yes \\
\hline
\end{tabular}


Table 4: Conditional Logit Regression Results of SAT Mismatch on Application Choices for Students with High SATs (Upper Quartile of the SAT Distribution)

\begin{tabular}{|c|c|c|c|c|c|c|c|c|c|c|c|c|}
\hline \multirow[b]{3}{*}{ Campus fit and cost: } & \multicolumn{4}{|c|}{ Panel A: Baseline Specification } & \multicolumn{4}{|c|}{ Panel B: with Campus Demographics } & \multicolumn{4}{|c|}{ Panel C: with High School Peers } \\
\hline & \multicolumn{2}{|c|}{ Top $10 \%$} & \multicolumn{2}{|c|}{ Top $11-25 \%$} & \multicolumn{2}{|c|}{ Top $10 \%$} & \multicolumn{2}{|c|}{ Top $11-25 \%$} & \multicolumn{2}{|c|}{ Top $10 \%$} & \multicolumn{2}{|c|}{ Top $11-25 \%$} \\
\hline & $\begin{array}{c}\text { Low } \\
\text { income } \\
(1)\end{array}$ & $\begin{array}{c}\text { High } \\
\text { income } \\
(2)\end{array}$ & $\begin{array}{c}\text { Low } \\
\text { income } \\
(3)\end{array}$ & $\begin{array}{c}\text { High } \\
\text { income } \\
(4)\end{array}$ & $\begin{array}{c}\text { Low } \\
\text { income } \\
(5)\end{array}$ & $\begin{array}{c}\text { High } \\
\text { income } \\
(6)\end{array}$ & $\begin{array}{c}\text { Low } \\
\text { income } \\
(7)\end{array}$ & $\begin{array}{c}\text { High } \\
\text { income } \\
(8)\end{array}$ & $\begin{array}{l}\text { Low } \\
\text { income } \\
(9)\end{array}$ & $\begin{array}{c}\text { High } \\
\text { income } \\
(10)\end{array}$ & $\begin{array}{c}\text { Low } \\
\text { income } \\
(11)\end{array}$ & $\begin{array}{c}\text { High } \\
\text { income } \\
(12)\end{array}$ \\
\hline SAT undermatch (safety school) ${ }^{\mathrm{a}}$ & $\begin{array}{l}0.852 * \\
(0.058)\end{array}$ & $\begin{array}{l}1.676^{*} \\
(0.074)\end{array}$ & $\begin{array}{l}2.316^{*} \\
(0.246)\end{array}$ & $\begin{array}{l}3.705^{*} \\
(0.199)\end{array}$ & $\begin{array}{l}1.992 * \\
(0.146)\end{array}$ & $\begin{array}{l}2.285^{*} \\
(0.114)\end{array}$ & $\begin{array}{l}1.849 * \\
(0.200)\end{array}$ & $\begin{array}{l}2.221^{*} \\
(0.141)\end{array}$ & $\begin{array}{l}0.717 * \\
(0.046)\end{array}$ & $\begin{array}{c}1.027 \\
(0.041)\end{array}$ & $\begin{array}{l}1.960 * \\
(0.212)\end{array}$ & $\begin{array}{l}2.745^{*} \\
(0.151)\end{array}$ \\
\hline Can commute ( $<60$ miles $)$ & $\begin{array}{c}17.721 * \\
(1.298)\end{array}$ & $\begin{array}{c}7.233^{*} \\
(0.562)\end{array}$ & $\begin{array}{c}20.154^{*} \\
(2.166)\end{array}$ & $\begin{array}{c}6.661^{*} \\
(0.469)\end{array}$ & $\begin{array}{l}8.967 * \\
(0.896)\end{array}$ & $\begin{array}{l}4.364 * \\
(0.335)\end{array}$ & $\begin{array}{l}9.644^{*} \\
(1.175)\end{array}$ & $\begin{array}{l}3.800 * \\
(0.306)\end{array}$ & $\begin{array}{l}4.970^{*} \\
(0.449)\end{array}$ & $\begin{array}{l}2.618^{*} \\
(0.187)\end{array}$ & $\begin{array}{c}6.035^{*} \\
(0.726)\end{array}$ & $\begin{array}{l}2.452 * \\
(0.186)\end{array}$ \\
\hline Can visit home (60-250 miles) & $\begin{array}{l}5.664 * \\
(0.351)\end{array}$ & $\begin{array}{l}5.051 * \\
(0.295)\end{array}$ & $\begin{array}{l}4.405 * \\
(0.371)\end{array}$ & $\begin{array}{l}3.675^{*} \\
(0.179)\end{array}$ & $\begin{array}{l}3.370 * \\
(0.255)\end{array}$ & $\begin{array}{l}1.883 * \\
(0.102)\end{array}$ & $\begin{array}{l}3.505 * \\
(0.303)\end{array}$ & $\begin{array}{l}2.433 * \\
(0.125)\end{array}$ & $\begin{array}{l}3.142 * \\
(0.209)\end{array}$ & $\begin{array}{l}2.847 * \\
(0.175)\end{array}$ & $\begin{array}{l}2.932 * \\
(0.249)\end{array}$ & $\begin{array}{l}2.342 * \\
(0.115)\end{array}$ \\
\hline In-state tuition $(\$ 1,000)$ & $\begin{array}{l}2.060 * \\
(0.056)\end{array}$ & $\begin{array}{l}3.521 * \\
(0.105)\end{array}$ & $\begin{array}{c}1.825 * \\
(0.071)\end{array}$ & $\begin{array}{l}2.978 * \\
(0.107)\end{array}$ & $\begin{array}{l}1.432 * \\
(0.038)\end{array}$ & $\begin{array}{c}1.022 \\
(0.024)\end{array}$ & $\begin{array}{l}1.719 * \\
(0.060)\end{array}$ & $\begin{array}{l}1.471 * \\
(0.047)\end{array}$ & $\begin{array}{c}1.868 * \\
(0.048)\end{array}$ & $\begin{array}{l}2.543 * \\
(0.054)\end{array}$ & $\begin{array}{l}1.552 * \\
(0.055)\end{array}$ & $\begin{array}{l}1.994^{*} \\
(0.051)\end{array}$ \\
\hline Open enrollment campus & $\begin{array}{l}0.229 * \\
(0.028)\end{array}$ & $\begin{array}{l}0.250 * \\
(0.023)\end{array}$ & $\begin{array}{l}0.239 * \\
(0.034)\end{array}$ & $\begin{array}{l}0.158^{*} \\
(0.017)\end{array}$ & $\begin{array}{l}0.407^{*} \\
(0.054)\end{array}$ & $\begin{array}{c}0.859 \\
(0.086)\end{array}$ & $\begin{array}{l}0.389 * \\
(0.060)\end{array}$ & $\begin{array}{l}0.552^{*} \\
(0.065)\end{array}$ & $\begin{array}{l}0.332 * \\
(0.034)\end{array}$ & $\begin{array}{l}0.384^{*} \\
(0.029)\end{array}$ & $\begin{array}{l}0.297 * \\
(0.041)\end{array}$ & $\begin{array}{l}0.236^{*} \\
(0.025)\end{array}$ \\
\hline \multicolumn{13}{|c|}{ Campus demographics: } \\
\hline \multicolumn{5}{|c|}{ Applications from the same county (100's) } & $\begin{array}{l}1.058^{*} \\
(0.003)\end{array}$ & $\begin{array}{l}1.059 * \\
(0.003)\end{array}$ & $\begin{array}{l}1.066^{*} \\
(0.004)\end{array}$ & $\begin{array}{l}1.066^{*} \\
(0.004)\end{array}$ & & & & \\
\hline \multicolumn{5}{|l|}{$\%$ Same-race students } & $\begin{array}{l}0.261 * \\
(0.051)\end{array}$ & $\begin{array}{c}1.993 * \\
(0.397)\end{array}$ & $\begin{array}{l}0.258 * \\
(0.063)\end{array}$ & $\begin{array}{c}1.460 \\
(0.333)\end{array}$ & & & & \\
\hline \multicolumn{5}{|l|}{$\%$ Same-income students } & $\begin{array}{l}0.165 * \\
(0.057)\end{array}$ & $\begin{array}{l}1230.992 * \\
(314.289)\end{array}$ & $\begin{array}{l}0.239 * \\
(0.128)\end{array}$ & $\begin{array}{l}618.939 * \\
(185.301)\end{array}$ & & & & \\
\hline \multicolumn{5}{|l|}{$\%$ Same-rank students } & $\begin{array}{c}69.475^{*} \\
(12.119)\end{array}$ & $\begin{array}{c}176.203 * \\
(25.582)\end{array}$ & $\begin{array}{c}106.585 * \\
(36.181)\end{array}$ & $\begin{array}{c}15.066^{*} \\
(2.487)\end{array}$ & & & & \\
\hline \multicolumn{13}{|c|}{ High school peers: } \\
\hline \multicolumn{5}{|c|}{ Prior applicants from same high school } & & & & & $\begin{array}{l}1.049 * \\
(0.004)\end{array}$ & $\begin{array}{l}1.050 * \\
(0.002)\end{array}$ & $\begin{array}{c}1.030 * \\
(0.003)\end{array}$ & $\begin{array}{c}1.031 * \\
(0.003)\end{array}$ \\
\hline \multicolumn{5}{|l|}{ Prior enrollees from same high school } & & & & & $\begin{array}{l}0.983 * \\
(0.004)\end{array}$ & $\begin{array}{l}0.979 * \\
(0.003)\end{array}$ & $\begin{array}{c}1.004 \\
(0.005)\end{array}$ & $\begin{array}{c}0.997 \\
(0.006)\end{array}$ \\
\hline No. of students $\mathrm{x}$ campus obs & 81,933 & 313,937 & 35,216 & 123,938 & 81,933 & 313,937 & 35,216 & 123,938 & 81,933 & 313,937 & 35,216 & 123,938 \\
\hline No. of students & 2,643 & 10,127 & 1,136 & 3,998 & 2,643 & 10,127 & 1,136 & 3,998 & 2,643 & 10,127 & 1,136 & 3,998 \\
\hline
\end{tabular}

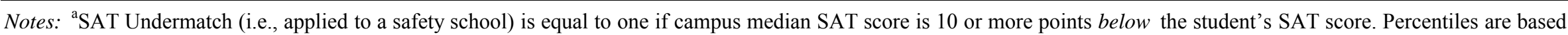

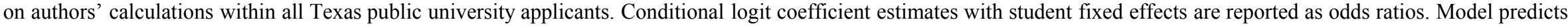

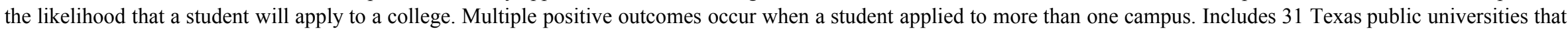

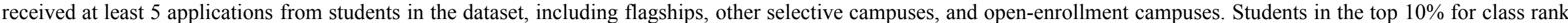

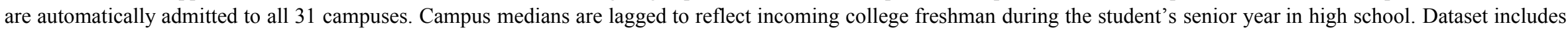

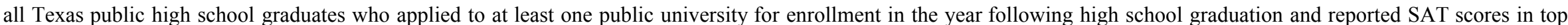
$25 \%$ of public university applicants. Standard errors are robust to clustering within high school attended. * indicates statistical significance at $\mathrm{p}<0.05$ level. 
Table 5: College Applicantion and Enrollment Rates for Students

in the Lower Quartile of the SAT Distribution (Low SATs) by High School Class Rank and Family Income

\begin{tabular}{|c|c|c|c|c|c|c|c|c|}
\hline & \multicolumn{4}{|c|}{ Panel A: Application } & \multicolumn{4}{|c|}{ Panel B: Enrollment } \\
\hline & \multicolumn{2}{|c|}{ Top $10 \%$} & \multicolumn{2}{|c|}{ Top $11-25 \%$} & \multicolumn{2}{|c|}{ Top $10 \%$} & \multicolumn{2}{|c|}{ Top $11-25 \%$} \\
\hline & $\begin{array}{c}\text { Low } \\
\text { income }\end{array}$ & $\begin{array}{c}\text { High } \\
\text { income }\end{array}$ & $\begin{array}{c}\text { Low } \\
\text { income }\end{array}$ & $\begin{array}{c}\text { High } \\
\text { income }\end{array}$ & $\begin{array}{c}\text { Low } \\
\text { income }\end{array}$ & $\begin{array}{c}\text { High } \\
\text { income }\end{array}$ & $\begin{array}{c}\text { Low } \\
\text { income }\end{array}$ & $\begin{array}{c}\text { High } \\
\text { income }\end{array}$ \\
\hline Average applications per student & 1.887 & 1.684 & 1.693 & 1.799 & 1.918 & 1.742 & 1.734 & 1.830 \\
\hline & $(1.283)$ & $(1.002)$ & $(1.130)$ & $(1.087)$ & $(1.279)$ & $(1.037)$ & $(1.155)$ & $(1.094)$ \\
\hline Average SAT score percentile difference & -33.319 & -38.750 & -26.924 & -30.747 & -34.569 & -43.610 & -24.242 & -30.130 \\
\hline & $(21.206)$ & $(19.509)$ & $(17.378)$ & $(16.419)$ & $(22.370)$ & $(19.335)$ & $(15.659)$ & $(15.629)$ \\
\hline \multicolumn{9}{|l|}{ SAT campus fit by 10 percentile points: } \\
\hline Safety school (undermatched) ${ }^{\mathrm{a}}$ & $<1 \%$ & $<1 \%$ & $<1 \%$ & $<1 \%$ & $<1 \%$ & $<1 \%$ & $<1 \%$ & $<1 \%$ \\
\hline Closely matched school (well-matched) ${ }^{b}$ & 0.276 & 0.103 & 0.254 & 0.134 & 0.134 & 0.046 & 0.133 & 0.059 \\
\hline Reach school (overmatched) ${ }^{c}$ & 0.880 & 0.971 & 0.863 & 0.967 & 0.606 & 0.690 & 0.544 & 0.684 \\
\hline \multicolumn{9}{|l|}{ Campus type: } \\
\hline Open enrollment campus (non-competitive) & 0.168 & 0.155 & 0.164 & 0.213 & 0.043 & 0.040 & 0.072 & 0.105 \\
\hline Flagship campus (highly competitive) & 0.287 & 0.483 & 0.074 & 0.146 & 0.180 & 0.322 & 0.009 & 0.050 \\
\hline Majority black or Hispanic campus & 0.470 & 0.195 & 0.540 & 0.220 & 0.247 & 0.092 & 0.296 & 0.113 \\
\hline Enrolled at a public university & 0.741 & 0.736 & 0.681 & 0.743 & -- & -- & -- & -- \\
\hline Number of students & 1,472 & 174 & 3,197 & 522 & 1,091 & 128 & 2,176 & 388 \\
\hline
\end{tabular}

Notes: Standard deviations are in parentheses for continuous variables. College enrollment based on fall semester following high school

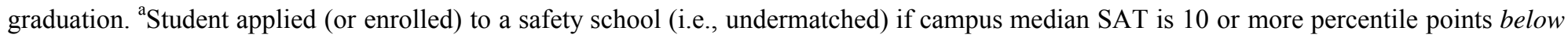

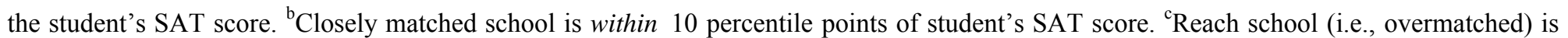
10 or more points above the student's SAT score. 
Table 6: Ordinary Least Squares Regression Results

of SAT Mismatch on Application and Enrollment Choices for Students with Low SATs (Lower Quartile of the SAT Distribution)

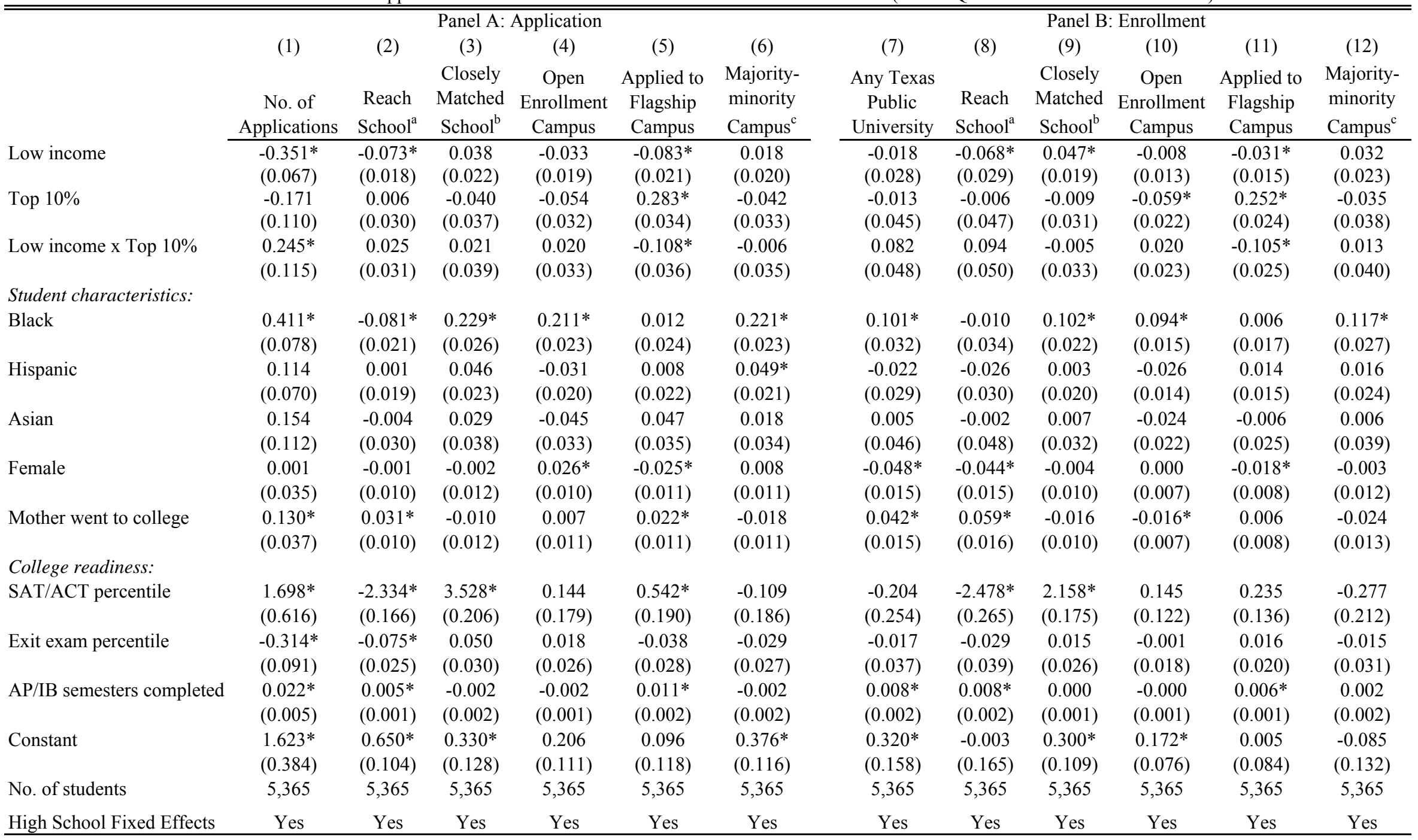

Notes: Column (1) is OLS model for number of applications. Columns (2)-(12) are linear probability models that predict the effect of income and top 10\% on students'

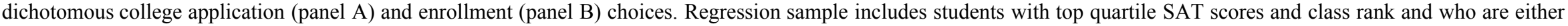

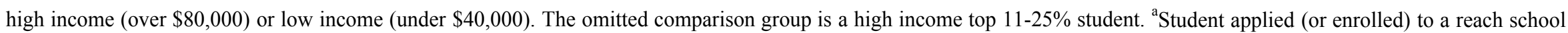

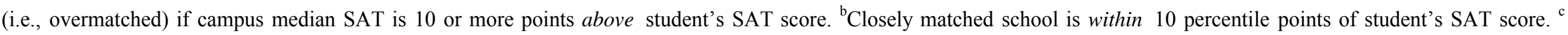
Majority-minority campus has student population that is more than 50 percent black and/or Hispanic students. * indicates statistical significance at $\mathrm{p}<0.05$ level. 
Table 7: Conditional Logit Regression Results of SAT Mismatch on Application Choices for Students with Low SATs (Lower Quartile of the SAT Distribution)

\begin{tabular}{|c|c|c|c|c|c|c|c|c|c|c|c|c|}
\hline \multirow[b]{3}{*}{ Campus fit and cost: } & \multicolumn{4}{|c|}{ Panel A: Baseline Specification } & \multicolumn{4}{|c|}{ Panel B: with Campus Demographics } & \multicolumn{4}{|c|}{ Panel C: with High School Peers } \\
\hline & \multicolumn{2}{|c|}{ Top $10 \%$} & \multicolumn{2}{|c|}{ Top $11-25 \%$} & \multicolumn{2}{|c|}{ Top $10 \%$} & \multicolumn{2}{|c|}{ Top $11-25 \%$} & \multicolumn{2}{|c|}{ Top $10 \%$} & \multicolumn{2}{|c|}{ Top $11-25 \%$} \\
\hline & $\begin{array}{l}\text { Low } \\
\text { income } \\
(1)\end{array}$ & $\begin{array}{c}\text { High } \\
\text { income } \\
(2)\end{array}$ & $\begin{array}{l}\text { Low } \\
\text { income } \\
(3)\end{array}$ & $\begin{array}{c}\text { High } \\
\text { income } \\
(4)\end{array}$ & $\begin{array}{l}\text { Low } \\
\text { income } \\
(5)\end{array}$ & $\begin{array}{c}\text { High } \\
\text { income } \\
(6)\end{array}$ & $\begin{array}{c}\text { Low } \\
\text { income } \\
(7)\end{array}$ & $\begin{array}{c}\text { High } \\
\text { income } \\
(8)\end{array}$ & $\begin{array}{l}\text { Low } \\
\text { income } \\
(9)\end{array}$ & $\begin{array}{c}\text { High } \\
\text { income } \\
(10)\end{array}$ & $\begin{array}{l}\text { Low } \\
\text { income } \\
(11)\end{array}$ & $\begin{array}{l}\text { High } \\
\text { income } \\
(12)\end{array}$ \\
\hline SAT overmatch (reach school) ${ }^{\mathrm{a}}$ & $\begin{array}{l}1.334^{*} \\
(0.129)\end{array}$ & $\begin{array}{l}2.651^{*} \\
(0.947)\end{array}$ & $\begin{array}{l}1.381^{*} \\
(0.100)\end{array}$ & $\begin{array}{l}3.584^{*} \\
(0.556)\end{array}$ & $\begin{array}{l}1.624 * \\
(0.143)\end{array}$ & $\begin{array}{c}1.889 \\
(0.724)\end{array}$ & $\begin{array}{l}1.650 * \\
(0.107)\end{array}$ & $\begin{array}{l}2.738 * \\
(0.435)\end{array}$ & $\begin{array}{l}1.872 * \\
(0.180)\end{array}$ & $\begin{array}{l}3.341 * \\
(1.245)\end{array}$ & $\begin{array}{l}1.565^{*} \\
(0.105)\end{array}$ & $\begin{array}{l}3.727 * \\
(0.569)\end{array}$ \\
\hline Can commute ( $<60$ miles $)$ & $\begin{array}{l}53.083 * \\
(6.849)\end{array}$ & $\begin{array}{l}30.644 * \\
(7.588)\end{array}$ & $\begin{array}{l}84.202 * \\
(9.631)\end{array}$ & $\begin{array}{c}27.088 * \\
(3.962)\end{array}$ & $\begin{array}{l}12.516^{*} \\
(2.083)\end{array}$ & $\begin{array}{l}19.753 * \\
(5.735)\end{array}$ & $\begin{array}{l}18.150 * \\
(2.442)\end{array}$ & $\begin{array}{l}16.009 * \\
(2.526)\end{array}$ & $\begin{array}{l}11.518^{*} \\
(1.619)\end{array}$ & $\begin{array}{l}12.817^{*} \\
(3.850)\end{array}$ & $\begin{array}{l}13.885^{*} \\
(1.655)\end{array}$ & $\begin{array}{l}9.736^{*} \\
(1.711)\end{array}$ \\
\hline Can visit home (60-250 miles) & $\begin{array}{l}7.129 * \\
(0.628)\end{array}$ & $\begin{array}{l}6.611^{*} \\
(1.313)\end{array}$ & $\begin{array}{l}9.818^{*} \\
(0.839)\end{array}$ & $\begin{array}{l}6.533^{*} \\
(0.839)\end{array}$ & $\begin{array}{l}3.492 * \\
(0.351)\end{array}$ & $\begin{array}{l}4.792 * \\
(1.055)\end{array}$ & $\begin{array}{l}5.153^{*} \\
(0.428)\end{array}$ & $\begin{array}{l}5.062^{*} \\
(0.641)\end{array}$ & $\begin{array}{l}4.195^{*} \\
(0.369)\end{array}$ & $\begin{array}{l}4.931 * \\
(1.013)\end{array}$ & $\begin{array}{l}5.507 * \\
(0.476)\end{array}$ & $\begin{array}{l}4.772 * \\
(0.616)\end{array}$ \\
\hline In-state tuition & $\begin{array}{l}1.255^{*} \\
(0.039)\end{array}$ & $\begin{array}{l}1.475^{*} \\
(0.086)\end{array}$ & $\begin{array}{l}0.896^{*} \\
(0.028)\end{array}$ & $\begin{array}{c}1.037 \\
(0.031)\end{array}$ & $\begin{array}{c}1.057 \\
(0.038)\end{array}$ & $\begin{array}{l}0.796^{*} \\
(0.062)\end{array}$ & $\begin{array}{l}0.919^{*} \\
(0.030)\end{array}$ & $\begin{array}{l}0.864 * \\
(0.034)\end{array}$ & $\begin{array}{l}1.259 * \\
(0.035)\end{array}$ & $\begin{array}{l}1.469 * \\
(0.088)\end{array}$ & $\begin{array}{l}0.906^{*} \\
(0.021)\end{array}$ & $\begin{array}{c}0.993 \\
(0.032)\end{array}$ \\
\hline Open enrollment campus & $\begin{array}{l}0.512 * \\
(0.054)\end{array}$ & $\begin{array}{c}0.673 \\
(0.156)\end{array}$ & $\begin{array}{l}0.536^{*} \\
(0.037)\end{array}$ & $\begin{array}{l}0.693 * \\
(0.076)\end{array}$ & $\begin{array}{c}0.859 \\
(0.091)\end{array}$ & $\begin{array}{c}1.173 \\
(0.256)\end{array}$ & $\begin{array}{l}0.866^{*} \\
(0.059)\end{array}$ & $\begin{array}{c}1.115 \\
(0.129)\end{array}$ & $\begin{array}{l}0.617^{*} \\
(0.055)\end{array}$ & $\begin{array}{c}0.828 \\
(0.194)\end{array}$ & $\begin{array}{l}0.684 * \\
(0.043)\end{array}$ & $\begin{array}{c}0.847 \\
(0.094)\end{array}$ \\
\hline \multicolumn{13}{|c|}{ Campus demographics: } \\
\hline \multicolumn{5}{|c|}{ Applications from the same county (100's) } & $\begin{array}{l}1.050 * \\
(0.003)\end{array}$ & $\begin{array}{l}1.037^{*} \\
(0.007)\end{array}$ & $\begin{array}{l}1.050 * \\
(0.002)\end{array}$ & $\begin{array}{c}1.034 * \\
(0.003)\end{array}$ & & & & \\
\hline \multicolumn{5}{|l|}{$\%$ Same-race students } & $\begin{array}{l}3.541^{*} \\
(0.592)\end{array}$ & $\begin{array}{l}7.802^{*} \\
(3.556)\end{array}$ & $\begin{array}{l}4.072^{*} \\
(0.566)\end{array}$ & $\begin{array}{l}5.733^{*} \\
(1.481)\end{array}$ & & & & \\
\hline \multicolumn{5}{|l|}{$\%$ Same-income students } & $\begin{array}{l}2.696^{*} \\
(1.218)\end{array}$ & $\begin{array}{l}246.724 * \\
(214.113)\end{array}$ & $\begin{array}{l}4.262^{*} \\
(1.310)\end{array}$ & $\begin{array}{l}25.833^{*} \\
(10.715)\end{array}$ & & & & \\
\hline \multicolumn{5}{|l|}{$\%$ Same-rank students } & $\begin{array}{l}4.267 * \\
(0.969)\end{array}$ & $\begin{array}{l}8.842 * \\
(4.020)\end{array}$ & $\begin{array}{c}26.383 * \\
(7.696)\end{array}$ & $\begin{array}{l}28.847^{*} \\
(12.078)\end{array}$ & & & & \\
\hline \multicolumn{13}{|c|}{ High school peers: } \\
\hline \multicolumn{5}{|c|}{ Prior applicants from same high school } & & & & & $\begin{array}{l}1.040 * \\
(0.008)\end{array}$ & $\begin{array}{l}1.033 * \\
(0.013)\end{array}$ & $\begin{array}{c}1.041 * \\
(0.005)\end{array}$ & $\begin{array}{l}1.030^{*} \\
(0.006)\end{array}$ \\
\hline Prior enrollees from same high s & & & & & & & & & $\begin{array}{c}1.013 \\
(0.009)\end{array}$ & $\begin{array}{c}0.987 \\
(0.014)\end{array}$ & $\begin{array}{c}1.007 \\
(0.007)\end{array}$ & $\begin{array}{c}0.999 \\
(0.007)\end{array}$ \\
\hline No. of students x campus obs & 45,632 & 5,394 & 99,107 & 16,182 & 45,632 & 5,394 & 99,107 & 16,182 & 45,632 & 5,394 & 99,107 & 16,182 \\
\hline No. of students & 1,472 & 174 & 3,197 & 522 & 1,472 & 174 & 3,197 & 522 & 1,472 & 174 & 3,197 & 522 \\
\hline
\end{tabular}

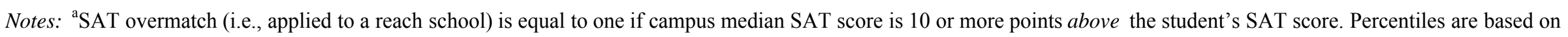

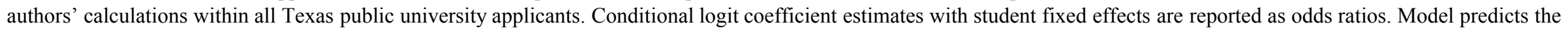

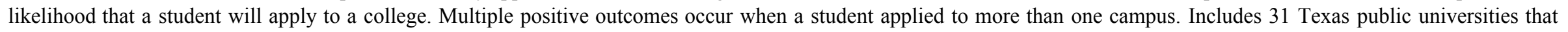

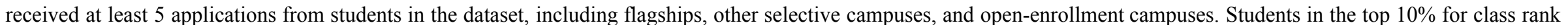

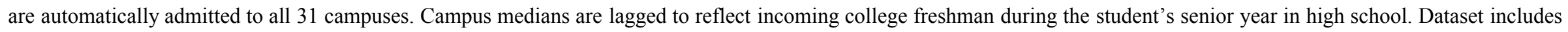

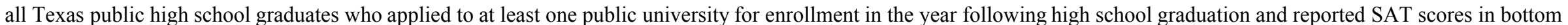
$25 \%$ of public university applicants. Standard errors are robust to clustering within high school attended. * indicates statistical significance at $\mathrm{p}<0.05$ level. 
Appendix 1: Characteristics of Enrollees at Texas 4-Year Public Universities

\begin{tabular}{|c|c|c|c|c|c|c|c|}
\hline Institution Name & Campus Type & $\begin{array}{l}\text { Mean SAT (2007 } \\
\text { freshmen) }\end{array}$ & $\begin{array}{l}\text { In-state } \\
\text { tuition }\end{array}$ & $\%$ Black & $\%$ Hispanic & $\%$ Low-income & $\%$ Tор 10 \\
\hline 1) University of Texas at Austin & Flagship campus & 1213 & $\$ 6,972$ & $6.7 \%$ & $19.7 \%$ & $21.7 \%$ & $69 \%$ \\
\hline 2) Texas A\&M University & Flagship campus & 1167 & $\$ 6,399$ & $4.1 \%$ & $14.5 \%$ & $15.1 \%$ & $42 \%$ \\
\hline 3) Sam Houston State University & Other top $10 \%$ campus & 1004 & $\$ 3,500$ & $18.1 \%$ & $12.6 \%$ & $9.4 \%$ & $11 \%$ \\
\hline 4) Stephen F. Austin State University & Other top $10 \%$ campus & 973 & $\$ 2,752$ & $21.5 \%$ & $9.7 \%$ & $26.1 \%$ & $12 \%$ \\
\hline 5) Texas A\&M University - Commerce & Other top $10 \%$ campus & 1003 & $\$ 3,650$ & $27.5 \%$ & $9.4 \%$ & $18.8 \%$ & $13 \%$ \\
\hline 6) Texas A\&M University - Corpus Christi & Other top $10 \%$ campus & 968 & $\$ 3,150$ & $5.7 \%$ & $41.7 \%$ & $32.1 \%$ & $13 \%$ \\
\hline 7) Texas A\&M University - International & Other top $10 \%$ campus & 872 & $\$ 4,678$ & $<1 \%$ & $90.1 \%$ & $35.0 \%$ & $14 \%$ \\
\hline 8) Texas A\&M University - Kingsville & Other top $10 \%$ campus & 898 & $\$ 3,200$ & $6.8 \%$ & $64.2 \%$ & $36.5 \%$ & $13 \%$ \\
\hline 9) Texas State University - San Marcos & Other top $10 \%$ campus & 1060 & $\$ 5,252$ & $5.4 \%$ & $22.4 \%$ & $21.6 \%$ & $11 \%$ \\
\hline 10) Texas Tech University & Other top $10 \%$ campus & 1089 & $\$ 6,151$ & $4.1 \%$ & $12.3 \%$ & $12.0 \%$ & $17 \%$ \\
\hline 11) Texas A\&M University Galveston & Other top $10 \%$ campus & 1055 & $\$ 5,100$ & $2.4 \%$ & $10.2 \%$ & $12.6 \%$ & $7 \%$ \\
\hline 12) University of Houston & Other top $10 \%$ campus & 1059 & $\$ 4,000$ & $20.0 \%$ & $22.9 \%$ & $9.7 \%$ & $29 \%$ \\
\hline 13) University of North Texas & Other top $10 \%$ campus & 1069 & $\$ 3,300$ & $15.2 \%$ & $11.8 \%$ & $18.3 \%$ & $13 \%$ \\
\hline 14) University of Texas - Brownsville & Other top $10 \%$ campus & 965 & $\$ 4,425$ & $<1 \%$ & $81.7 \%$ & $11.0 \%$ & $14 \%$ \\
\hline 15) University of Texas - Pan American & Other top $10 \%$ campus & 921 & $\$ 2,957$ & $<1 \%$ & $88.0 \%$ & $9.8 \%$ & $14 \%$ \\
\hline 16) University of Texas - San Antonio & Other top $10 \%$ campus & 1004 & $\$ 5,520$ & $9.3 \%$ & $38.1 \%$ & $24.6 \%$ & $8 \%$ \\
\hline 17) University of Texas - Arlington & Other top $10 \%$ campus & 1061 & $\$ 3,070$ & $12.4 \%$ & $17.2 \%$ & $23.5 \%$ & $16 \%$ \\
\hline 18) University of Texas - Dallas & Other top $10 \%$ campus & 1221 & $\$ 6,832$ & $5.6 \%$ & $9.4 \%$ & $19.4 \%$ & $29 \%$ \\
\hline 19) University of Texas - El Paso & Other top $10 \%$ campus & 912 & $\$ 4,822$ & $4.1 \%$ & $74.8 \%$ & $3.9 \%$ & $11 \%$ \\
\hline 20) University of Texas - Tyler & Other top $10 \%$ campus & 922 & $\$ 4,114$ & $6.6 \%$ & $8.2 \%$ & $23.8 \%$ & $19 \%$ \\
\hline 21) University of Texas of the Permian Basin & Other top $10 \%$ campus & 961 & $\$ 4,519$ & $6.8 \%$ & $39.9 \%$ & $31.2 \%$ & $12 \%$ \\
\hline 22) University of Houston Downtown & Other top $10 \%$ campus & 868 & $\$ 3,326$ & $29.7 \%$ & $48.6 \%$ & $5.5 \%$ & $3 \%$ \\
\hline 23) West Texas A\&M University & Other top $10 \%$ campus & 979 & $\$ 3,756$ & $6.8 \%$ & $20.9 \%$ & $3.6 \%$ & $25 \%$ \\
\hline 24) Prairie View A\&M University & Open enrollment HBCU & 837 & $\$ 4,906$ & $94.6 \%$ & $3.3 \%$ & $26.9 \%$ & $9 \%$ \\
\hline 25) Texas Southern University & Open enrollment HBCU & 793 & $\$ 3,772$ & $92.6 \%$ & $3.3 \%$ & $6.6 \%$ & $4 \%$ \\
\hline 26) Angelo State University & Open enrollment not HBCU & 960 & $\$ 3,521$ & $8.4 \%$ & $26.8 \%$ & $18.5 \%$ & $9 \%$ \\
\hline 27) Lamar University - Beaumont & Open enrollment not HBCU & 899 & $\$ 2,620$ & $33.6 \%$ & $7.6 \%$ & $10.5 \%$ & $13 \%$ \\
\hline 28) Midwestern State University & Open enrollment not HBCU & 1016 & $\$ 4,461$ & $14.2 \%$ & $10.8 \%$ & $26.6 \%$ & $7 \%$ \\
\hline 29) Sul Ross State University & Open enrollment not $\mathrm{HBCU}$ & 840 & $\$ 2,800$ & $7.9 \%$ & $47.5 \%$ & $40.6 \%$ & $6 \%$ \\
\hline 30) Tarleton State University & Open enrollment not HBCU & 978 & $\$ 3,438$ & $4.4 \%$ & $9.9 \%$ & $24.4 \%$ & $8 \%$ \\
\hline 31) Texas Woman's University & Open enrollment not HBCU & 967 & $\$ 3,100$ & $28.1 \%$ & $19.1 \%$ & $31.3 \%$ & $13 \%$ \\
\hline
\end{tabular}

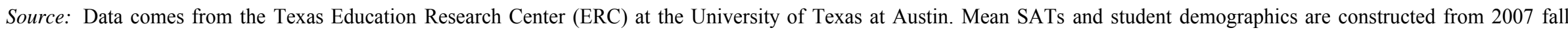
freshmen enrollment. Tuition comes from the Integrated Postsecondary Education Data System (IPEDS) and Barron's (if missing in IPEDS). 
Appendix 2: Conditional Logit Regression Results of SAT Mismatch on Enrollment Choices for Students with High SATs (Upper Quartile of the SAT Distribution)

\begin{tabular}{|c|c|c|c|c|c|c|c|c|c|c|c|c|}
\hline \multirow[b]{3}{*}{ Campus fit and cost: } & \multicolumn{4}{|c|}{ Panel A: Baseline Specification } & \multicolumn{4}{|c|}{ Panel B: with Campus Demographics } & \multicolumn{4}{|c|}{ Panel C: with High School Peers } \\
\hline & \multicolumn{2}{|c|}{ Top $10 \%$} & \multicolumn{2}{|c|}{ Top $11-25 \%$} & \multicolumn{2}{|c|}{ Top $10 \%$} & \multicolumn{2}{|c|}{ Top $11-25 \%$} & \multicolumn{2}{|c|}{ Top $10 \%$} & \multicolumn{2}{|c|}{ Top $11-25 \%$} \\
\hline & $\begin{array}{l}\text { Low } \\
\text { income } \\
(1)\end{array}$ & $\begin{array}{c}\text { High } \\
\text { income } \\
(2)\end{array}$ & $\begin{array}{c}\text { Low } \\
\text { income } \\
(3)\end{array}$ & $\begin{array}{c}\text { High } \\
\text { income } \\
(4)\end{array}$ & $\begin{array}{c}\text { Low } \\
\text { income } \\
(5)\end{array}$ & $\begin{array}{c}\text { High } \\
\text { income } \\
(6)\end{array}$ & $\begin{array}{c}\text { Low } \\
\text { income } \\
(7)\end{array}$ & $\begin{array}{c}\text { High } \\
\text { income } \\
(8)\end{array}$ & $\begin{array}{c}\text { Low } \\
\text { income } \\
(9)\end{array}$ & $\begin{array}{c}\text { High } \\
\text { income } \\
(10)\end{array}$ & $\begin{array}{c}\text { Low } \\
\text { income } \\
(11)\end{array}$ & $\begin{array}{c}\text { High } \\
\text { income } \\
(12)\end{array}$ \\
\hline SAT undermatch (safety school) ${ }^{\mathrm{a}}$ & $\begin{array}{l}0.751 * \\
(0.065)\end{array}$ & $\begin{array}{l}1.519 * \\
(0.075)\end{array}$ & $\begin{array}{l}2.436^{*} \\
(0.353)\end{array}$ & $\begin{array}{l}3.339 * \\
(0.224)\end{array}$ & $\begin{array}{l}1.557^{*} \\
(0.141)\end{array}$ & $\begin{array}{l}1.563 * \\
(0.081)\end{array}$ & $\begin{array}{l}1.911 * \\
(0.282)\end{array}$ & $\begin{array}{l}2.057 * \\
(0.153)\end{array}$ & $\begin{array}{l}0.655^{*} \\
(0.056)\end{array}$ & $\begin{array}{c}1.020 \\
(0.051)\end{array}$ & $\begin{array}{l}2.103 * \\
(0.316)\end{array}$ & $\begin{array}{l}2.427 * \\
(0.171)\end{array}$ \\
\hline Can commute ( $<60$ miles $)$ & $\begin{array}{l}19.764 * \\
(2.058)\end{array}$ & $\begin{array}{l}6.804^{*} \\
(0.610)\end{array}$ & $\begin{array}{c}26.920^{*} \\
(3.764)\end{array}$ & $\begin{array}{c}7.680 * \\
(0.664)\end{array}$ & $\begin{array}{c}10.765^{*} \\
(1.367)\end{array}$ & $\begin{array}{l}5.054^{*} \\
(0.438)\end{array}$ & $\begin{array}{l}13.712 * \\
(2.030)\end{array}$ & $\begin{array}{l}4.923^{*} \\
(0.449)\end{array}$ & $\begin{array}{l}6.536^{*} \\
(0.750)\end{array}$ & $\begin{array}{l}2.906^{*} \\
(0.266)\end{array}$ & $\begin{array}{l}9.996^{*} \\
(1.463)\end{array}$ & $\begin{array}{l}3.242 * \\
(0.305)\end{array}$ \\
\hline Can visit home (60-250 miles) & $\begin{array}{l}6.415 * \\
(0.591)\end{array}$ & $\begin{array}{l}4.987^{*} \\
(0.366)\end{array}$ & $\begin{array}{l}5.381 * \\
(0.671)\end{array}$ & $\begin{array}{l}4.276^{*} \\
(0.304)\end{array}$ & $\begin{array}{l}3.476^{*} \\
(0.361)\end{array}$ & $\begin{array}{l}2.133^{*} \\
(0.148)\end{array}$ & $\begin{array}{l}4.120 * \\
(0.514)\end{array}$ & $\begin{array}{l}2.803 * \\
(0.205)\end{array}$ & $\begin{array}{l}3.440 * \\
(0.310)\end{array}$ & $\begin{array}{l}2.790 * \\
(0.225)\end{array}$ & $\begin{array}{l}3.904^{*} \\
(0.500)\end{array}$ & $\begin{array}{l}2.795^{*} \\
(0.217)\end{array}$ \\
\hline In-state tuition & $\begin{array}{l}1.984^{*} \\
(0.068)\end{array}$ & $\begin{array}{l}3.693^{*} \\
(0.126)\end{array}$ & $\begin{array}{l}1.662 * \\
(0.072)\end{array}$ & $\begin{array}{l}2.836^{*} \\
(0.116)\end{array}$ & $\begin{array}{l}1.395^{*} \\
(0.050)\end{array}$ & $\begin{array}{c}1.054 \\
(0.033)\end{array}$ & $\begin{array}{l}1.612 * \\
(0.064)\end{array}$ & $\begin{array}{l}1.530^{*} \\
(0.062)\end{array}$ & $\begin{array}{l}1.879 * \\
(0.065)\end{array}$ & $\begin{array}{l}2.842^{*} \\
(0.088)\end{array}$ & $\begin{array}{l}1.529 * \\
(0.065)\end{array}$ & $\begin{array}{l}2.000 * \\
(0.069)\end{array}$ \\
\hline Open enrollment campus & $\begin{array}{l}0.247^{*} \\
(0.043)\end{array}$ & $\begin{array}{l}0.280^{*} \\
(0.036)\end{array}$ & $\begin{array}{l}0.263^{*} \\
(0.053)\end{array}$ & $\begin{array}{l}0.180^{*} \\
(0.028)\end{array}$ & $\begin{array}{l}0.439 * \\
(0.080)\end{array}$ & $\begin{array}{c}0.912 \\
(0.132)\end{array}$ & $\begin{array}{l}0.382 * \\
(0.081)\end{array}$ & $\begin{array}{l}0.582 * \\
(0.104)\end{array}$ & $\begin{array}{l}0.346^{*} \\
(0.049)\end{array}$ & $\begin{array}{l}0.392 * \\
(0.044)\end{array}$ & $\begin{array}{l}0.275^{*} \\
(0.048)\end{array}$ & $\begin{array}{c}0.231 * \\
(0.035)\end{array}$ \\
\hline \multicolumn{13}{|c|}{ Campus demographics: } \\
\hline \multicolumn{5}{|c|}{ Applications from the same county (100's) } & $\begin{array}{l}1.052 * \\
(0.003)\end{array}$ & $\begin{array}{l}1.057^{*} \\
(0.003)\end{array}$ & $\begin{array}{l}1.051 * \\
(0.004)\end{array}$ & $\begin{array}{l}1.055^{*} \\
(0.004)\end{array}$ & & & & \\
\hline \multicolumn{5}{|l|}{$\%$ Same-race students } & $\begin{array}{l}0.129 * \\
(0.035)\end{array}$ & $\begin{array}{c}1.372 \\
(0.346)\end{array}$ & $\begin{array}{l}0.132 * \\
(0.037)\end{array}$ & $\begin{array}{l}1.890 * \\
(0.556)\end{array}$ & & & & \\
\hline \multicolumn{5}{|l|}{$\%$ Same-income students } & $\begin{array}{l}0.057 * \\
(0.028)\end{array}$ & $\begin{array}{c}1642.345^{*} \\
(565.473)\end{array}$ & $\begin{array}{l}0.186^{*} \\
(0.129)\end{array}$ & $\begin{array}{l}282.959 * \\
(103.569)\end{array}$ & & & & \\
\hline \multicolumn{5}{|l|}{$\%$ Same-rank students } & $\begin{array}{l}56.099 * \\
(11.401)\end{array}$ & $\begin{array}{c}58.412 * \\
(8.338)\end{array}$ & $\begin{array}{l}45.866^{*} \\
(19.052)\end{array}$ & $\begin{array}{l}8.960 * \\
(1.836)\end{array}$ & & & & \\
\hline \multicolumn{13}{|c|}{ High school peers: } \\
\hline \multicolumn{5}{|c|}{ Prior applicants from same high school } & & & & & $\begin{array}{l}1.035^{*} \\
(0.004)\end{array}$ & $\begin{array}{l}1.033^{*} \\
(0.002)\end{array}$ & $\begin{array}{c}1.016^{*} \\
(0.003)\end{array}$ & $\begin{array}{c}1.023 * \\
(0.003)\end{array}$ \\
\hline \multicolumn{5}{|l|}{ Prior enrollees from same high school } & & & & & $\begin{array}{l}0.987 * \\
(0.004)\end{array}$ & $\begin{array}{l}0.989 * \\
(0.003)\end{array}$ & $\begin{array}{c}1.008 \\
(0.004)\end{array}$ & $\begin{array}{c}0.999 \\
(0.005)\end{array}$ \\
\hline No. of students $\mathrm{x}$ campus obs & 64,015 & 226,858 & 28,737 & 95,201 & 64,015 & 226,858 & 28,737 & 95,201 & 64,015 & 226,858 & 28,737 & 95,201 \\
\hline No. of students & 2,065 & 7,318 & 927 & 3,071 & 2,065 & 7,318 & 927 & 3,071 & 2,065 & 7,318 & 927 & 3,071 \\
\hline
\end{tabular}

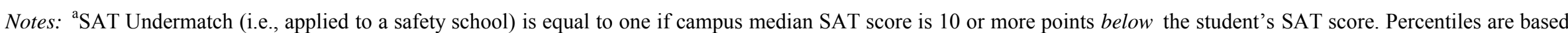

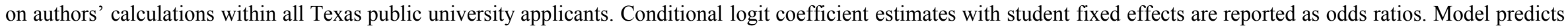

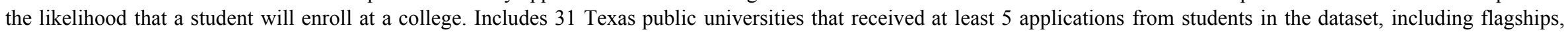

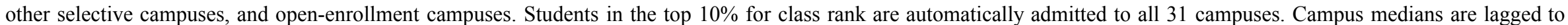

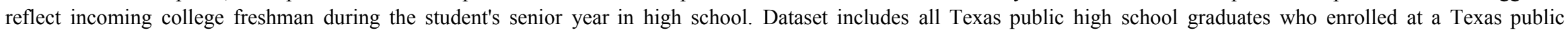

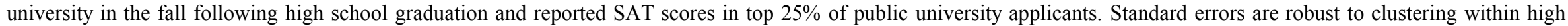
school attended. * indicates statistical significance at $\mathrm{p}<0.05$ level. 
Appendix 3: Summary Statistics of Applicants at Texas Public Institutions by SATs, High School Class Rank, and Family Incomı

\begin{tabular}{|c|c|c|c|c|c|c|c|c|c|c|c|c|c|c|c|c|}
\hline \multirow[b]{4}{*}{ Student characteristics: } & \multicolumn{8}{|c|}{ Panel A: No Data Exclusions from Analytic Sample } & \multicolumn{8}{|c|}{ Panel B: Excludes Those who Always Undermatch/Overmatch from Analytic Sample } \\
\hline & \multicolumn{4}{|c|}{ Low SATs } & \multicolumn{4}{|c|}{ High SATs } & \multicolumn{4}{|c|}{ Low SATs } & \multicolumn{4}{|c|}{ High SATs } \\
\hline & \multicolumn{2}{|c|}{ Top $10 \%$} & \multicolumn{2}{|c|}{ Top $11-25 \%$} & \multicolumn{2}{|c|}{ Top $10 \%$} & \multicolumn{2}{|c|}{ Top $11-25 \%$} & \multicolumn{2}{|c|}{ Top $10 \%$} & \multicolumn{2}{|c|}{ Top $11-25 \%$} & \multicolumn{2}{|c|}{ Top $10 \%$} & \multicolumn{2}{|c|}{ Top $11-25 \%$} \\
\hline & $\begin{array}{c}\text { Low } \\
\text { income }\end{array}$ & $\begin{array}{c}\text { High } \\
\text { income }\end{array}$ & $\begin{array}{c}\text { Low } \\
\text { income }\end{array}$ & $\begin{array}{l}\text { High } \\
\text { income }\end{array}$ & $\begin{array}{c}\text { Low } \\
\text { income }\end{array}$ & $\begin{array}{c}\text { High } \\
\text { income }\end{array}$ & $\begin{array}{c}\text { Low } \\
\text { income }\end{array}$ & $\begin{array}{c}\text { High } \\
\text { income }\end{array}$ & $\begin{array}{c}\text { Low } \\
\text { income }\end{array}$ & $\begin{array}{c}\text { High } \\
\text { income }\end{array}$ & $\begin{array}{c}\text { Low } \\
\text { income }\end{array}$ & $\begin{array}{l}\text { High } \\
\text { income }\end{array}$ & $\begin{array}{c}\text { Low } \\
\text { income }\end{array}$ & $\begin{array}{c}\text { High } \\
\text { income }\end{array}$ & $\begin{array}{c}\text { Low } \\
\text { income }\end{array}$ & $\begin{array}{c}\text { High } \\
\text { income }\end{array}$ \\
\hline Black & 0.239 & 0.144 & 0.200 & 0.159 & 0.043 & 0.018 & 0.044 & 0.022 & 0.239 & 0.147 & 0.197 & 0.159 & 0.049 & 0.025 & 0.046 & 0.025 \\
\hline Hispanic & 0.660 & 0.351 & 0.682 & 0.316 & 0.256 & 0.079 & 0.244 & 0.073 & 0.665 & 0.359 & 0.684 & 0.321 & 0.295 & 0.095 & 0.259 & 0.081 \\
\hline Asian & 0.048 & 0.034 & 0.027 & 0.025 & 0.199 & 0.134 & 0.104 & 0.072 & 0.048 & 0.035 & 0.027 & 0.023 & 0.173 & 0.078 & 0.094 & 0.053 \\
\hline Female & 0.759 & 0.695 & 0.709 & 0.663 & 0.555 & 0.530 & 0.482 & 0.461 & 0.760 & 0.706 & 0.707 & 0.663 & 0.581 & 0.574 & 0.496 & 0.489 \\
\hline Mother went to college & 0.266 & 0.736 & 0.293 & 0.755 & 0.530 & 0.877 & 0.547 & 0.853 & 0.266 & 0.735 & 0.291 & 0.751 & 0.500 & 0.851 & 0.528 & 0.840 \\
\hline \multicolumn{17}{|l|}{ College readiness: } \\
\hline SAT score & $\begin{array}{l}812.17 \\
(74.04)\end{array}$ & $\begin{array}{l}826.21 \\
(73.31)\end{array}$ & $\begin{array}{l}804.88 \\
(76.78)\end{array}$ & $\begin{array}{l}830.53 \\
(68.20)\end{array}$ & $\begin{array}{r}1274.63 \\
(87.61)\end{array}$ & $\begin{array}{l}1326.20 \\
(106.26)\end{array}$ & $\begin{array}{r}1244.92 \\
(71.40)\end{array}$ & $\begin{array}{r}1279.01 \\
(88.50)\end{array}$ & $\begin{array}{l}818.93 \\
(60.80)\end{array}$ & $\begin{array}{l}832.79 \\
(59.32)\end{array}$ & $\begin{array}{l}813.09 \\
(61.53)\end{array}$ & $\begin{array}{l}836.61 \\
(53.87)\end{array}$ & $\begin{array}{r}1237.13 \\
(50.46)\end{array}$ & $\begin{array}{r}1252.34 \\
(52.13)\end{array}$ & $\begin{array}{r}1227.92 \\
(48.71)\end{array}$ & $\begin{array}{r}1240.37 \\
(52.07)\end{array}$ \\
\hline SAT percentile & $\begin{array}{c}0.148 \\
(0.069)\end{array}$ & $\begin{array}{c}0.166 \\
(0.069)\end{array}$ & $\begin{array}{c}0.140 \\
(0.068)\end{array}$ & $\begin{array}{c}0.169 \\
(0.064)\end{array}$ & $\begin{array}{c}0.870 \\
(0.070)\end{array}$ & $\begin{array}{c}0.906 \\
(0.071)\end{array}$ & $\begin{array}{c}0.846 \\
(0.064)\end{array}$ & $\begin{array}{c}0.874 \\
(0.071)\end{array}$ & $\begin{array}{c}0.152 \\
(0.066)\end{array}$ & $\begin{array}{c}0.170 \\
(0.065)\end{array}$ & $\begin{array}{c}0.144 \\
(0.065)\end{array}$ & $\begin{array}{c}0.172 \\
(0.060)\end{array}$ & $\begin{array}{c}0.843 \\
(0.054)\end{array}$ & $\begin{array}{c}0.859 \\
(0.054)\end{array}$ & $\begin{array}{c}0.833 \\
(0.054)\end{array}$ & $\begin{array}{c}0.846 \\
(0.056)\end{array}$ \\
\hline Exit exam percentile & $\begin{array}{c}0.552 \\
(0.215)\end{array}$ & $\begin{array}{c}0.588 \\
(0.196)\end{array}$ & $\begin{array}{c}0.455 \\
(0.205)\end{array}$ & $\begin{array}{c}0.537 \\
(0.194)\end{array}$ & $\begin{array}{c}0.899 \\
(0.143)\end{array}$ & $\begin{array}{c}0.912 \\
(0.131)\end{array}$ & $\begin{array}{c}0.823 \\
(0.181)\end{array}$ & $\begin{array}{c}0.854 \\
(0.165)\end{array}$ & $\begin{array}{c}0.553 \\
(0.213)\end{array}$ & $\begin{array}{c}0.583 \\
(0.194)\end{array}$ & $\begin{array}{c}0.458 \\
(0.204)\end{array}$ & $\begin{array}{c}0.535 \\
(0.191)\end{array}$ & $\begin{array}{c}0.891 \\
(0.142)\end{array}$ & $\begin{array}{c}0.896 \\
(0.131)\end{array}$ & $\begin{array}{c}0.816 \\
(0.181)\end{array}$ & $\begin{array}{c}0.844 \\
(0.159)\end{array}$ \\
\hline AP/IB semesters completed & $\begin{array}{c}5.874 \\
(4.261)\end{array}$ & $\begin{array}{c}4.856 \\
(3.777)\end{array}$ & $\begin{array}{c}3.600 \\
(3.643)\end{array}$ & $\begin{array}{c}3.462 \\
(3.596)\end{array}$ & $\begin{array}{l}10.759 \\
(5.812)\end{array}$ & $\begin{array}{l}12.170 \\
(5.776)\end{array}$ & $\begin{array}{c}7.684 \\
(5.460)\end{array}$ & $\begin{array}{c}9.010 \\
(5.368)\end{array}$ & $\begin{array}{c}5.873 \\
(4.264)\end{array}$ & $\begin{array}{c}4.888 \\
(3.811)\end{array}$ & $\begin{array}{c}3.610 \\
(3.643)\end{array}$ & $\begin{array}{c}3.429 \\
(3.554)\end{array}$ & $\begin{array}{l}10.067 \\
(5.503)\end{array}$ & $\begin{array}{l}10.337 \\
(5.196)\end{array}$ & $\begin{array}{c}7.240 \\
(5.180)\end{array}$ & $\begin{array}{c}8.064 \\
(4.931)\end{array}$ \\
\hline Missing exit exam & $\begin{array}{c}0.019 \\
(0.137)\end{array}$ & $\begin{array}{c}<1 \% \\
(0.076)\end{array}$ & $\begin{array}{c}0.026 \\
(0.159)\end{array}$ & $\begin{array}{c}0.017 \\
(0.130)\end{array}$ & $\begin{array}{c}<1 \% \\
(0.097)\end{array}$ & $\begin{array}{c}<1 \% \\
(0.085)\end{array}$ & $\begin{array}{c}0.012 \\
(0.110)\end{array}$ & $\begin{array}{l}<1 \% \\
(0.101)\end{array}$ & $\begin{array}{c}0.019 \\
(0.136)\end{array}$ & $\begin{array}{c}<1 \% \\
(0.077)\end{array}$ & $\begin{array}{c}0.025 \\
(0.156)\end{array}$ & $\begin{array}{c}0.016 \\
(0.124)\end{array}$ & $\begin{array}{c}<1 \% \\
(0.096)\end{array}$ & $\begin{array}{l}<1 \% \\
(0.079)\end{array}$ & $\begin{array}{c}0.014 \\
(0.116)\end{array}$ & $\begin{array}{c}<1 \% \\
(0.093)\end{array}$ \\
\hline $\begin{array}{l}\text { High school characteristics: } \\
\% \text { Black }\end{array}$ & $\begin{array}{c}0.203 \\
(0.276)\end{array}$ & $\begin{array}{c}0.170 \\
(0.211)\end{array}$ & $\begin{array}{c}0.138 \\
(0.216)\end{array}$ & $\begin{array}{c}0.144 \\
(0.161)\end{array}$ & $\begin{array}{c}0.135 \\
(0.141)\end{array}$ & $\begin{array}{c}0.116 \\
(0.107)\end{array}$ & $\begin{array}{c}0.111 \\
(0.123)\end{array}$ & $\begin{array}{c}0.095 \\
(0.090)\end{array}$ & $\begin{array}{c}0.203 \\
(0.276)\end{array}$ & $\begin{array}{c}0.169 \\
(0.213)\end{array}$ & $\begin{array}{c}0.135 \\
(0.213)\end{array}$ & $\begin{array}{c}0.144 \\
(0.162)\end{array}$ & $\begin{array}{c}0.136 \\
(0.144)\end{array}$ & $\begin{array}{c}0.123 \\
(0.114)\end{array}$ & $\begin{array}{c}0.112 \\
(0.125)\end{array}$ & $\begin{array}{c}0.100 \\
(0.094)\end{array}$ \\
\hline \% Hispanic & $\begin{array}{c}0.707 \\
(0.310)\end{array}$ & $\begin{array}{c}0.500 \\
(0.298)\end{array}$ & $\begin{array}{c}0.720 \\
(0.300)\end{array}$ & $\begin{array}{c}0.464 \\
(0.281)\end{array}$ & $\begin{array}{c}0.405 \\
(0.275)\end{array}$ & $\begin{array}{c}0.268 \\
(0.188)\end{array}$ & $\begin{array}{c}0.345 \\
(0.259)\end{array}$ & $\begin{array}{c}0.218 \\
(0.152)\end{array}$ & $\begin{array}{c}0.711 \\
(0.306)\end{array}$ & $\begin{array}{c}0.509 \\
(0.296)\end{array}$ & $\begin{array}{c}0.721 \\
(0.299)\end{array}$ & $\begin{array}{c}0.468 \\
(0.281)\end{array}$ & $\begin{array}{c}0.431 \\
(0.281)\end{array}$ & $\begin{array}{c}0.295 \\
(0.199)\end{array}$ & $\begin{array}{c}0.354 \\
(0.263)\end{array}$ & $\begin{array}{c}0.229 \\
(0.155)\end{array}$ \\
\hline$\%$ Free and reduced lunch & $\begin{array}{c}0.765 \\
(0.167)\end{array}$ & $\begin{array}{c}0.524 \\
(0.202)\end{array}$ & $\begin{array}{c}0.711 \\
(0.198)\end{array}$ & $\begin{array}{c}0.462 \\
(0.203)\end{array}$ & $\begin{array}{c}0.419 \\
(0.220)\end{array}$ & $\begin{array}{c}0.257 \\
(0.168)\end{array}$ & $\begin{array}{c}0.350 \\
(0.214)\end{array}$ & $\begin{array}{c}0.193 \\
(0.143)\end{array}$ & $\begin{array}{c}0.767 \\
(0.165)\end{array}$ & $\begin{array}{c}0.527 \\
(0.203)\end{array}$ & $\begin{array}{c}0.711 \\
(0.199)\end{array}$ & $\begin{array}{c}0.463 \\
(0.203)\end{array}$ & $\begin{array}{c}0.444 \\
(0.218)\end{array}$ & $\begin{array}{c}0.291 \\
(0.169)\end{array}$ & $\begin{array}{c}0.360 \\
(0.215)\end{array}$ & $\begin{array}{c}0.207 \\
(0.143)\end{array}$ \\
\hline$\%$ Advanced Placement (AP) tested & $\begin{array}{c}0.201 \\
(0.122)\end{array}$ & $\begin{array}{c}0.169 \\
(0.107)\end{array}$ & $\begin{array}{c}0.195 \\
(0.115)\end{array}$ & $\begin{array}{c}0.177 \\
(0.099)\end{array}$ & $\begin{array}{c}0.214 \\
(0.131)\end{array}$ & $\begin{array}{c}0.277 \\
(0.148)\end{array}$ & $\begin{array}{c}0.247 \\
(0.154)\end{array}$ & $\begin{array}{c}0.328 \\
(0.160)\end{array}$ & $\begin{array}{c}0.201 \\
(0.123)\end{array}$ & $\begin{array}{c}0.168 \\
(0.107)\end{array}$ & $\begin{array}{c}0.194 \\
(0.114)\end{array}$ & $\begin{array}{c}0.177 \\
(0.099)\end{array}$ & $\begin{array}{c}0.204 \\
(0.123)\end{array}$ & $\begin{array}{c}0.244 \\
(0.128)\end{array}$ & $\begin{array}{c}0.236 \\
(0.144)\end{array}$ & $\begin{array}{c}0.304 \\
(0.147)\end{array}$ \\
\hline$\%$ four-year college entrants & $\begin{array}{c}0.242 \\
(0.118)\end{array}$ & $\begin{array}{c}0.265 \\
(0.107)\end{array}$ & $\begin{array}{c}0.284 \\
(0.134)\end{array}$ & $\begin{array}{c}0.289 \\
(0.114)\end{array}$ & $\begin{array}{c}0.324 \\
(0.136)\end{array}$ & $\begin{array}{c}0.393 \\
(0.132)\end{array}$ & $\begin{array}{c}0.371 \\
(0.146)\end{array}$ & $\begin{array}{c}0.446 \\
(0.129)\end{array}$ & $\begin{array}{c}0.243 \\
(0.119)\end{array}$ & $\begin{array}{c}0.266 \\
(0.107)\end{array}$ & $\begin{array}{c}0.286 \\
(0.135)\end{array}$ & $\begin{array}{c}0.290 \\
(0.114)\end{array}$ & $\begin{array}{c}0.311 \\
(0.131)\end{array}$ & $\begin{array}{c}0.361 \\
(0.122)\end{array}$ & $\begin{array}{c}0.361 \\
(0.140)\end{array}$ & $\begin{array}{c}0.425 \\
(0.124)\end{array}$ \\
\hline Distance to any 4-yr public university & $\begin{array}{l}15.54 \\
(16.11)\end{array}$ & $\begin{array}{l}22.62 \\
(20.79)\end{array}$ & $\begin{array}{l}17.99 \\
(18.55)\end{array}$ & $\begin{array}{l}22.29 \\
(19.51)\end{array}$ & $\begin{array}{l}21.44 \\
(20.06)\end{array}$ & $\begin{array}{l}18.88 \\
(16.80)\end{array}$ & $\begin{array}{l}20.59 \\
(19.69)\end{array}$ & $\begin{array}{l}16.81 \\
(13.97)\end{array}$ & $\begin{array}{l}15.62 \\
(16.26)\end{array}$ & $\begin{array}{l}22.78 \\
(20.98)\end{array}$ & $\begin{array}{l}18.07 \\
(18.65)\end{array}$ & $\begin{array}{l}22.40 \\
(19.61)\end{array}$ & $\begin{array}{l}21.91 \\
(20.50)\end{array}$ & $\begin{array}{l}20.26 \\
(17.88)\end{array}$ & $\begin{array}{l}20.69 \\
(19.71)\end{array}$ & $\begin{array}{l}17.45 \\
(14.57)\end{array}$ \\
\hline Distance to a flagship university & $\begin{array}{l}201.02 \\
(150.25)\end{array}$ & $\begin{array}{l}157.45 \\
(107.89)\end{array}$ & $\begin{array}{l}217.03 \\
(150.95)\end{array}$ & $\begin{array}{l}146.49 \\
(94.50)\end{array}$ & $\begin{array}{l}154.11 \\
(113.36)\end{array}$ & $\begin{array}{l}123.41 \\
(87.31)\end{array}$ & $\begin{array}{l}149.85 \\
(113.10)\end{array}$ & $\begin{array}{l}110.75 \\
(78.49)\end{array}$ & $\begin{array}{l}201.40 \\
(150.68)\end{array}$ & $\begin{array}{c}157.55 \\
(109.16)\end{array}$ & $\begin{array}{l}216.95 \\
(149.98)\end{array}$ & $\begin{array}{l}146.69 \\
(95.32)\end{array}$ & $\begin{array}{l}157.44 \\
(116.92)\end{array}$ & $\begin{array}{l}129.26 \\
(91.55)\end{array}$ & $\begin{array}{l}152.37 \\
(115.14)\end{array}$ & $\begin{array}{l}113.74 \\
(79.10)\end{array}$ \\
\hline Number of students & 1,472 & 174 & 3,197 & 522 & 2,643 & 10,127 & 1,136 & 3,998 & 1,434 & 170 & 3,094 & 511 & 2,063 & 5,993 & 1,023 & 3,086 \\
\hline
\end{tabular}

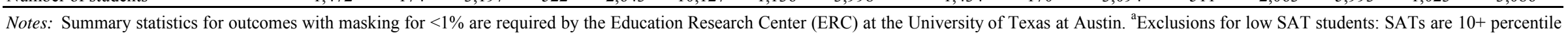

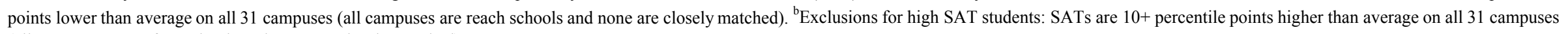
(all campuses are safety schools and none are closely matched). 
Appendix 4: Conditional Logit Regression Results of SAT Mismatch on Application and Enrollment Choices for Students with High SATs (Upper Quartile of the SAT Distribution) with Exclusions

\begin{tabular}{|c|c|c|c|c|c|c|c|c|}
\hline & \multicolumn{4}{|c|}{ Panel A: Application } & \multicolumn{4}{|c|}{ Panel B: Enrollment } \\
\hline & \multicolumn{2}{|c|}{ Top $10 \%$} & \multicolumn{2}{|c|}{ Top $11-25 \%$} & \multicolumn{2}{|c|}{ Top $10 \%$} & \multicolumn{2}{|c|}{ Top $11-25 \%$} \\
\hline & $\begin{array}{c}\text { Low } \\
\text { income }\end{array}$ & $\begin{array}{c}\text { High } \\
\text { income }\end{array}$ & $\begin{array}{c}\text { Low } \\
\text { income }\end{array}$ & $\begin{array}{l}\text { High } \\
\text { income }\end{array}$ & $\begin{array}{c}\text { Low } \\
\text { income }\end{array}$ & $\begin{array}{c}\text { High } \\
\text { income }\end{array}$ & $\begin{array}{c}\text { Low } \\
\text { income }\end{array}$ & $\begin{array}{l}\text { High } \\
\text { income }\end{array}$ \\
\hline Campus fit and cost: & $(1)$ & $(2)$ & $(3)$ & $(4)$ & $(1)$ & $(2)$ & $(3)$ & $(4)$ \\
\hline SAT undermatch (safety school) ${ }^{\mathrm{a}}$ & $\begin{array}{l}0.604 * \\
(0.055)\end{array}$ & $\begin{array}{l}1.209 * \\
(0.065)\end{array}$ & $\begin{array}{l}2.081 * \\
(0.234)\end{array}$ & $\begin{array}{l}3.487^{*} \\
(0.202)\end{array}$ & $\begin{array}{l}0.560 * \\
(0.067)\end{array}$ & $\begin{array}{l}1.142 * \\
(0.072)\end{array}$ & $\begin{array}{l}2.182 * \\
(0.338)\end{array}$ & $\begin{array}{l}3.116^{*} \\
(0.234)\end{array}$ \\
\hline Can commute ( $<60$ miles) & $\begin{array}{l}19.486 * \\
(1.540)\end{array}$ & $\begin{array}{l}7.775 * \\
(0.512)\end{array}$ & $\begin{array}{l}21.124 * \\
(2.354)\end{array}$ & $\begin{array}{l}6.941 * \\
(0.481)\end{array}$ & $\begin{array}{c}20.538 * \\
(2.276)\end{array}$ & $\begin{array}{l}7.339 * \\
(0.618)\end{array}$ & $\begin{array}{c}28.026^{*} \\
(4.007)\end{array}$ & $\begin{array}{l}7.615 * \\
(0.648)\end{array}$ \\
\hline Can visit home (60-250 miles) & $\begin{array}{l}5.543 * \\
(0.375)\end{array}$ & $\begin{array}{l}4.631 * \\
(0.262)\end{array}$ & $\begin{array}{l}4.310 * \\
(0.379)\end{array}$ & $\begin{array}{l}3.496 * \\
(0.155)\end{array}$ & $\begin{array}{l}6.250 * \\
(0.633)\end{array}$ & $\begin{array}{l}4.790 * \\
(0.361)\end{array}$ & $\begin{array}{l}5.287^{*} \\
(0.684)\end{array}$ & $\begin{array}{l}4.006 * \\
(0.285)\end{array}$ \\
\hline In-state tuition $(\$ 1,000)$ & $\begin{array}{c}1.779 * \\
(0.062)\end{array}$ & $\begin{array}{l}2.913 * \\
(0.093)\end{array}$ & $\begin{array}{l}1.747 * \\
(0.071)\end{array}$ & $\begin{array}{l}2.896^{*} \\
(0.101)\end{array}$ & $\begin{array}{c}1.744 * \\
(0.079)\end{array}$ & $\begin{array}{l}3.058^{*} \\
(0.119)\end{array}$ & $\begin{array}{l}1.590 * \\
(0.074)\end{array}$ & $\begin{array}{l}2.742 * \\
(0.110)\end{array}$ \\
\hline Open enrollment campus & $\begin{array}{l}0.232 * \\
(0.031)\end{array}$ & $\begin{array}{l}0.264 * \\
(0.023)\end{array}$ & $\begin{array}{l}0.241 * \\
(0.034)\end{array}$ & $\begin{array}{l}0.167 * \\
(0.018)\end{array}$ & $\begin{array}{l}0.247 * \\
(0.048)\end{array}$ & $\begin{array}{l}0.282^{*} \\
(0.037)\end{array}$ & $\begin{array}{l}0.268 * \\
(0.053)\end{array}$ & $\begin{array}{l}0.193 * \\
(0.029)\end{array}$ \\
\hline $\begin{array}{l}\text { No. of students x campus obs } \\
\text { No. of students }\end{array}$ & $\begin{array}{c}63,953 \\
2,063\end{array}$ & $\begin{array}{c}185,783 \\
5,993\end{array}$ & $\begin{array}{c}31,713 \\
1,023\end{array}$ & $\begin{array}{c}95,666 \\
3,086\end{array}$ & $\begin{array}{c}51,584 \\
1,664\end{array}$ & $\begin{array}{c}147,157 \\
4,747\end{array}$ & $\begin{array}{c}26,102 \\
842\end{array}$ & $\begin{array}{l}74,648 \\
2,408\end{array}$ \\
\hline
\end{tabular}

Notes: Appendix 4 replicates the results reported in Table 4 of panel A and Appendix 2, excluding students who are always undermatched on public university campuses. Conditional logit coefficient estimates with student fixed effects are reported as odds ratios. Model predicts the likelihood that a student will apply to a college (panel A) and enroll at a college (panel B). Multiple positive outcomes occur when a student applied to more than one campus. Includes 31 Texas public universities that received at least 5 applications from students in the dataset, including flagships, other selective campuses, and open-enrollment campuses. Students in the top $10 \%$ for class rank are automatically admitted to all 31 campuses. aSAT undermatch (i.e., applied to a safety school) is equal to one if campus SAT score is 10 or more points below the student's SAT score. Percentiles are based on authors' calculations within all Texas public university applicants. Campus medians are lagged to reflect incoming college freshman during the student's senior year in high school. Dataset includes all Texas public high school graduates who applied to at least one public university for enrollment in the year following high school graduation and reported SAT scores in top $25 \%$ of public university applicants. Standard errors are robust to clustering within high school attended. * indicates statistical significance at $\mathrm{p}<0.05$ level. 
Appendix 5: Conditional Logit Regression Results of SAT Mismatch on Enrollment Choices for Students with Low SATs (Lower Quartile of the SAT Distribution)

\begin{tabular}{|c|c|c|c|c|c|c|c|c|c|c|c|c|}
\hline \multirow[b]{3}{*}{ Campus fit and cost: } & \multicolumn{4}{|c|}{ Panel A: Baseline Specification } & \multicolumn{4}{|c|}{ Panel B: with Campus Demographics } & \multicolumn{4}{|c|}{ Panel C: with High School Peers } \\
\hline & \multicolumn{2}{|c|}{ Top $10 \%$} & \multicolumn{2}{|c|}{ Top $11-25 \%$} & \multicolumn{2}{|c|}{ Top $10 \%$} & \multicolumn{2}{|c|}{ Top $11-25 \%$} & \multicolumn{2}{|c|}{ Top $10 \%$} & \multicolumn{2}{|c|}{ Top $11-25 \%$} \\
\hline & $\begin{array}{c}\text { Low } \\
\text { income } \\
(1)\end{array}$ & $\begin{array}{c}\text { High } \\
\text { income } \\
(2)\end{array}$ & $\begin{array}{c}\text { Low } \\
\text { income } \\
(3)\end{array}$ & $\begin{array}{c}\text { High } \\
\text { income } \\
(4)\end{array}$ & $\begin{array}{c}\text { Low } \\
\text { income } \\
(5)\end{array}$ & $\begin{array}{c}\text { High } \\
\text { income } \\
(6)\end{array}$ & $\begin{array}{c}\text { Low } \\
\text { income } \\
(7)\end{array}$ & $\begin{array}{c}\text { High } \\
\text { income } \\
(8)\end{array}$ & $\begin{array}{c}\text { Low } \\
\text { income } \\
(9)\end{array}$ & $\begin{array}{c}\text { High } \\
\text { income } \\
(10)\end{array}$ & $\begin{array}{c}\text { Low } \\
\text { income } \\
(11)\end{array}$ & $\begin{array}{c}\text { High } \\
\text { income } \\
(12)\end{array}$ \\
\hline SAT overmatch (reach school) ${ }^{\mathrm{a}}$ & $\begin{array}{c}1.074 \\
(0.117)\end{array}$ & $\begin{array}{c}2.432 \\
(1.454)\end{array}$ & $\begin{array}{c}1.245^{*} \\
(0.108)\end{array}$ & $\begin{array}{l}3.609 * \\
(0.765)\end{array}$ & $\begin{array}{l}1.280 * \\
(0.158)\end{array}$ & $\begin{array}{c}1.210 \\
(0.705)\end{array}$ & $\begin{array}{l}1.742 * \\
(0.150)\end{array}$ & $\begin{array}{l}3.082 * \\
(0.690)\end{array}$ & $\begin{array}{l}1.531 * \\
(0.198)\end{array}$ & $\begin{array}{l}3.491 * \\
(1.889)\end{array}$ & $\begin{array}{l}1.587 * \\
(0.148)\end{array}$ & $\begin{array}{l}4.920 * \\
(1.154)\end{array}$ \\
\hline Can commute ( $<60$ miles) & $\begin{array}{c}73.754 * \\
(11.927)\end{array}$ & $\begin{array}{c}23.456^{*} \\
(8.160)\end{array}$ & $\begin{array}{c}190.197 * \\
(27.003)\end{array}$ & $\begin{array}{c}34.618^{*} \\
(7.812)\end{array}$ & $\begin{array}{l}16.782 * \\
(2.896)\end{array}$ & $\begin{array}{l}16.778^{*} \\
(6.425)\end{array}$ & $\begin{array}{c}46.844 * \\
(7.637)\end{array}$ & $\begin{array}{l}19.312^{*} \\
(4.606)\end{array}$ & $\begin{array}{c}25.821 * \\
(4.131)\end{array}$ & $\begin{array}{l}11.762 * \\
(4.358)\end{array}$ & $\begin{array}{c}52.553 * \\
(8.332)\end{array}$ & $\begin{array}{c}11.910^{*} \\
(2.856)\end{array}$ \\
\hline Can visit home (60-250 miles) & $\begin{array}{l}9.967 * \\
(1.628)\end{array}$ & $\begin{array}{l}5.876^{*} \\
(1.729)\end{array}$ & $\begin{array}{c}16.525^{*} \\
(2.208)\end{array}$ & $\begin{array}{l}6.953 * \\
(1.510)\end{array}$ & $\begin{array}{l}3.928^{*} \\
(0.634)\end{array}$ & $\begin{array}{l}4.225^{*} \\
(1.456)\end{array}$ & $\begin{array}{l}8.609 * \\
(1.177)\end{array}$ & $\begin{array}{l}5.210^{*} \\
(1.140)\end{array}$ & $\begin{array}{l}6.381 * \\
(0.928)\end{array}$ & $\begin{array}{l}4.360 * \\
(1.323)\end{array}$ & $\begin{array}{l}10.391 * \\
(1.402)\end{array}$ & $\begin{array}{l}4.827^{*} \\
(1.030)\end{array}$ \\
\hline In-state tuition & $\begin{array}{c}1.310 * \\
(0.048)\end{array}$ & $\begin{array}{c}1.666^{*} \\
(0.134)\end{array}$ & $\begin{array}{l}0.782 * \\
(0.025)\end{array}$ & $\begin{array}{c}0.994 \\
(0.041)\end{array}$ & $\begin{array}{c}1.015 \\
(0.045)\end{array}$ & $\begin{array}{c}0.819 \\
(0.101)\end{array}$ & $\begin{array}{c}0.876 * \\
(0.026)\end{array}$ & $\begin{array}{l}0.871 * \\
(0.050)\end{array}$ & $\begin{array}{c}1.368 * \\
(0.048)\end{array}$ & $\begin{array}{c}1.700 * \\
(0.139)\end{array}$ & $\begin{array}{c}0.859 * \\
(0.024)\end{array}$ & $\begin{array}{c}1.006 \\
(0.044)\end{array}$ \\
\hline Open enrollment campus & $\begin{array}{c}0.296^{*} \\
(0.048)\end{array}$ & $\begin{array}{c}0.467 \\
(0.219)\end{array}$ & $\begin{array}{l}0.487^{*} \\
(0.044)\end{array}$ & $\begin{array}{c}0.785 \\
(0.120)\end{array}$ & $\begin{array}{c}0.567 * \\
(0.086)\end{array}$ & $\begin{array}{c}0.823 \\
(0.378)\end{array}$ & $\begin{array}{c}0.744^{*} \\
(0.067)\end{array}$ & $\begin{array}{c}1.344 \\
(0.228)\end{array}$ & $\begin{array}{c}0.371 * \\
(0.056)\end{array}$ & $\begin{array}{c}0.610 \\
(0.276)\end{array}$ & $\begin{array}{c}0.605^{*} \\
(0.055)\end{array}$ & $\begin{array}{c}0.958 \\
(0.151)\end{array}$ \\
\hline \multicolumn{13}{|c|}{ Campus demographics: } \\
\hline \multicolumn{5}{|c|}{ Applications from the same county (100's) } & $\begin{array}{l}1.040 * \\
(0.003)\end{array}$ & $\begin{array}{l}1.034 * \\
(0.008)\end{array}$ & $\begin{array}{l}1.036^{*} \\
(0.002)\end{array}$ & $\begin{array}{l}1.032 * \\
(0.004)\end{array}$ & & & & \\
\hline \multicolumn{5}{|l|}{$\%$ Same-race students } & $\begin{array}{c}2.974 * \\
(0.700)\end{array}$ & $\begin{array}{c}4.033 \\
(3.661)\end{array}$ & $\begin{array}{l}5.130 * \\
(0.827)\end{array}$ & $\begin{array}{c}7.080 * \\
(2.604)\end{array}$ & & & & \\
\hline \multicolumn{5}{|l|}{$\%$ Same-income students } & $\begin{array}{c}2.712 \\
(1.429)\end{array}$ & $\begin{array}{l}570.273^{*} \\
(705.796)\end{array}$ & $\begin{array}{c}10.662 * \\
(4.245)\end{array}$ & $\begin{array}{l}23.840^{*} \\
(13.274)\end{array}$ & & & & \\
\hline \multicolumn{5}{|l|}{$\%$ Same-rank students } & $\begin{array}{l}15.937 * \\
(5.040)\end{array}$ & $\begin{array}{c}10.570 * \\
(6.735)\end{array}$ & $\begin{array}{l}39.286^{*} \\
(15.221)\end{array}$ & $\begin{array}{l}34.497^{*} \\
(19.555)\end{array}$ & & & & \\
\hline \multicolumn{13}{|c|}{ High school peers: } \\
\hline \multicolumn{5}{|c|}{ Prior applicants from same high school } & & & & & $\begin{array}{c}1.005 \\
(0.005)\end{array}$ & $\begin{array}{c}1.027 \\
(0.018)\end{array}$ & $\begin{array}{c}1.006^{*} \\
(0.003)\end{array}$ & $\begin{array}{c}1.011 \\
(0.006)\end{array}$ \\
\hline Prior enrollees from same high s & 1001 & & & & & & & & $\begin{array}{c}1.022 * \\
(0.006)\end{array}$ & $\begin{array}{c}0.982 \\
(0.020)\end{array}$ & $\begin{array}{c}1.019 * \\
(0.004)\end{array}$ & $\begin{array}{l}1.015^{*} \\
(0.007)\end{array}$ \\
\hline No. of students $\mathrm{x}$ campus obs & 33,821 & 3,968 & 67,456 & 12,028 & 33,821 & 3,968 & 67,456 & 12,028 & 33,821 & 3,968 & 67,456 & 12,028 \\
\hline No. of students & 1,091 & 128 & 2,176 & 388 & 1,091 & 128 & 2,176 & 388 & 1,091 & 128 & 2,176 & 388 \\
\hline
\end{tabular}

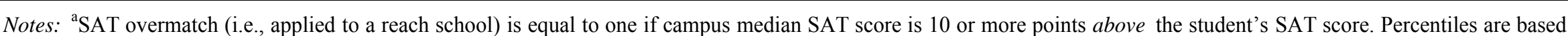

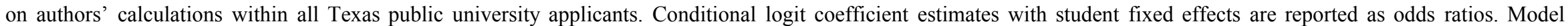

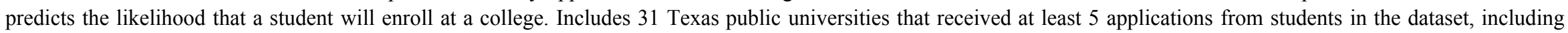

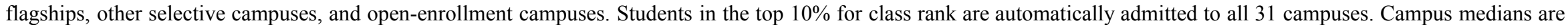

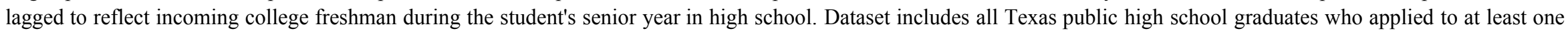

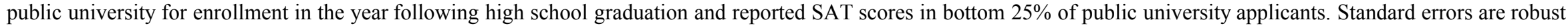
to clustering within high school attended. * indicates statistical significance at $\mathrm{p}<0.05$ level. 